\title{
Factors That Influence Nitrous Oxide Emissions from Agricultural Soils as Well as Their Representation in Simulation Models: A Review
}

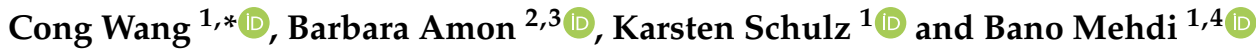 \\ 1 Department of Water, Atmosphere and Environment, Institute for Hydrology and Water Management, \\ University of Natural Resources \& Life Science, 1190 Vienna, Austria; karsten.schulz@boku.ac.at (K.S.); \\ bano.mehdi@boku.ac.at (B.M.) \\ 2 Leibniz Institute for Agricultural Engineering and Bioeconomy, 14469 Potsdam, Germany; \\ bamon@atb-potsdam.de \\ 3 Faculty of Civil Engineering, Architecture and Environmental Engineering, University of Zielona Góra, \\ Licealna 9/9, 65-417 Zielona Góra, Poland \\ 4 Department of Crop Science, Institute of Agronomy, University of Natural Resources \& Life Science, \\ 3430 Tulln an der Donau, Austria \\ * Correspondence: cong.wang@boku.ac.at
}

Citation: Wang, C.; Amon, B.; Schulz, K.; Mehdi, B. Factors That Influence

Nitrous Oxide Emissions from

Agricultural Soils as Well as Their Representation in Simulation Models: A Review. Agronomy 2021, 11, 770. https://doi.org/10.3390/

agronomy11040770

Academic Editor: Francis Drummond

Received: 11 March 2021

Accepted: 10 April 2021

Published: 14 April 2021

Publisher's Note: MDPI stays neutral with regard to jurisdictional claims in published maps and institutional affiliations.

Copyright: (c) 2021 by the authors. Licensee MDPI, Basel, Switzerland. This article is an open access article distributed under the terms and conditions of the Creative Commons Attribution (CC BY) license (https:/ / creativecommons.org/licenses/by/ $4.0 /)$.
Abstract: Nitrous oxide $\left(\mathrm{N}_{2} \mathrm{O}\right)$ is a long-lived greenhouse gas that contributes to global warming. Emissions of $\mathrm{N}_{2} \mathrm{O}$ mainly stem from agricultural soils. This review highlights the principal factors from peer-reviewed literature affecting $\mathrm{N}_{2} \mathrm{O}$ emissions from agricultural soils, by grouping the factors into three categories: environmental, management and measurement. Within these categories, each impact factor is explained in detail and its influence on $\mathrm{N}_{2} \mathrm{O}$ emissions from the soil is summarized. It is also shown how each impact factor influences other impact factors. Process-based simulation models used for estimating $\mathrm{N}_{2} \mathrm{O}$ emissions are reviewed regarding their ability to consider the impact factors in simulating $\mathrm{N}_{2} \mathrm{O}$. The model strengths and weaknesses in simulating $\mathrm{N}_{2} \mathrm{O}$ emissions from managed soils are summarized. Finally, three selected process-based simulation models (Daily Century (DAYCENT), DeNitrification-DeComposition (DNDC), and Soil and Water Assessment Tool (SWAT)) are discussed that are widely used to simulate $\mathrm{N}_{2} \mathrm{O}$ emissions from cropping systems. Their ability to simulate $\mathrm{N}_{2} \mathrm{O}$ emissions is evaluated by describing the model components that are relevant to $\mathrm{N}_{2} \mathrm{O}$ processes and their representation in the model.

Keywords: denitrification; nitrification; $\mathrm{N}_{2} \mathrm{O}$ impact factor; $\mathrm{N}_{2} \mathrm{O}$ modelling; emission factors

\section{Introduction}

Agricultural activities are responsible for two-thirds of the total anthropogenic nitrous oxide $\left(\mathrm{N}_{2} \mathrm{O}\right)$ emissions worldwide [1]. Most of the $\mathrm{N}_{2} \mathrm{O}$ emissions stem from fertilizer and animal manure application [2-5]. A main reason for $\mathrm{N}_{2} \mathrm{O}$ emissions from agricultural soils is the application of inorganic fertilizers and/or manure when the crops cannot uptake all of the applied nitrogen $(\mathrm{N})$ due to the growth stage not requiring all of it. This excess $\mathrm{N}$ in the soil environment leads to a lower than maximum nitrogen use efficiency [6-8]. With agricultural activities intensifying globally, $\mathrm{N}_{2} \mathrm{O}$ emissions are presently increasing at a rate of $0.25 \%$ per year [2]. Between 2001 and 2011, $\mathrm{N}_{2} \mathrm{O}$ emissions from agricultural soils increased overall, with contributions from Asia (63\%), the Americas (20\%), Europe $(13 \%)$ and Africa (3\%) [9]. In some parts of the world in recent years, a reduction in $\mathrm{N}_{2} \mathrm{O}$ emissions can be detected. For example, in Europe in 2016, a decrease in $\mathrm{N}_{2} \mathrm{O}$ emissions of 37\% from 1990 levels was reported, due to both European and country specific policies on agriculture and the environment that reduced the amount of reactive nitrogen being emitted into the environment [10].

The global warming potential (GWP) is the internationally agreed method published by the Intergovernmental Panel on Climate Change (IPCC) to convert greenhouse gases 
(GHG) into $\mathrm{CO}_{2}$ equivalents. The GWP is defined as the time-integrated radiative forcing due to a pulse emission of a given component, relative to a pulse emission of an equal mass of $\mathrm{CO}_{2}$ [8]. Based on a 100-year GWP level, the GWP of $\mathrm{N}_{2} \mathrm{O}$ emissions has been 298 times as potent as $\mathrm{CO}_{2}$ as a factor in global warming [8]. $\mathrm{N}_{2} \mathrm{O}$ emissions are responsible for $6 \%$ of annual global GHG emissions in terms of $\mathrm{CO}_{2}$ equivalent [11].

The IPCC also uses a metric known as the emission factor (EF) for $\mathrm{N}_{2} \mathrm{O}$, which is calculated as $\mathrm{kg} \mathrm{N} \mathrm{N}_{2} \mathrm{O}-\mathrm{N} / \mathrm{kg} \mathrm{N}$ input, and can be used to compare $\mathrm{N}_{2} \mathrm{O}$ emissions under different conditions [12-14]. Until 2019, the default method for calculating the EF for direct $\mathrm{N}_{2} \mathrm{O}$ emissions from managed soils was to use a linear factor equal to $1 \%$ of the total $\mathrm{N}$ amount applied to the soil. In 2019, the IPCC revised and updated the default EF based on a much larger number of measurements available to estimate $\mathrm{N}_{2} \mathrm{O}$ emissions from managed soils $[13,15]$. From its Tier 1 level of methodological complexity, which corresponds to the basic method using data on fertilizer production, import/export, or sales data, the revised emission factors for direct and indirect emissions of $\mathrm{N}_{2} \mathrm{O}$ are now disaggregated by climate zone as well as by fertilizer type. In wet climates, the default EF has been set at $0.6 \%$ of organic $\mathrm{N}$ inputs and $1.6 \%$ of synthetic $\mathrm{N}$ inputs. In dry climates, the default $\mathrm{EF}$ has been set at $0.5 \%$ of $\mathrm{N}$ inputs for both organic and synthetic $\mathrm{N}$ [13].

The principal processes causing $\mathrm{N}_{2} \mathrm{O}$ emissions in the soil are nitrification, nitrifier denitrification, and denitrification [1,16]. These are shown in Figure 1. Nitrification is the microbial oxidation of ammonium $\left(\mathrm{NH}_{4}{ }^{+}\right)$to nitrate $\left(\mathrm{NO}_{3}{ }^{-}\right)$, with $\mathrm{N}_{2} \mathrm{O}$ emitted as a by-product. Nitrifier denitrification is the reduction of nitrite $\left(\mathrm{NO}_{2}{ }^{-}\right)$to nitrogen monoxide (NO), then to $\mathrm{N}_{2} \mathrm{O}$, and finally to dinitrogen $\left(\mathrm{N}_{2}\right)$. Denitrification is a two-step process whereby $\mathrm{NO}_{3}{ }^{-}$is converted to $\mathrm{N}_{2} \mathrm{O}$ and then into inert $\mathrm{N}_{2}$ under anaerobic conditions. In the denitrification pathway, $\mathrm{NO}_{2}{ }^{-}, \mathrm{NO}$ and $\mathrm{N}_{2} \mathrm{O}$ are obligate intermediates.

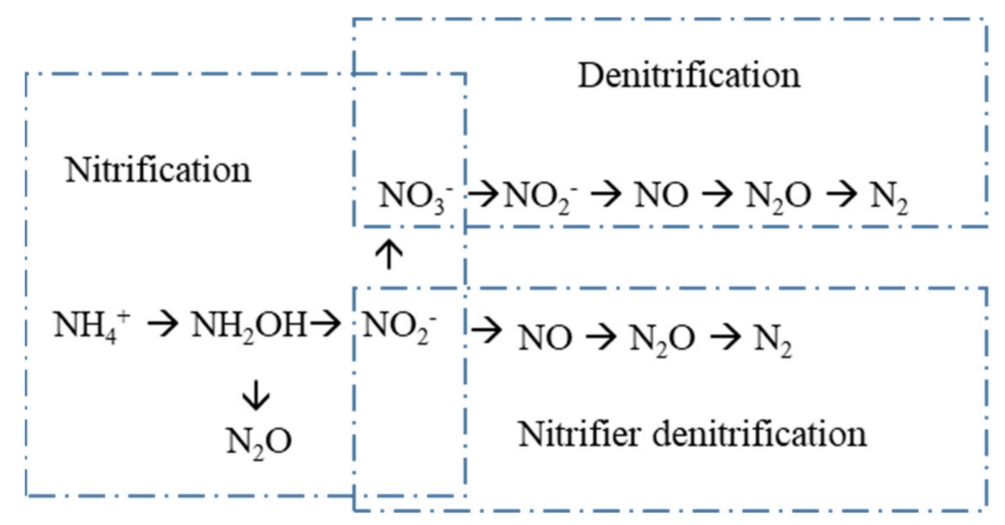

Figure 1. Principle $\mathrm{N}$ transformations leading to the emission of $\mathrm{N}_{2} \mathrm{O}$ in soils.

A number of factors regulate $\mathrm{N}_{2} \mathrm{O}$ emissions during the nitrification and denitrification processes. Such factors include the soil N concentration, soil moisture, soil temperature, fertilizer application amounts, and land use management [17]. Careful consideration of these impact factors in estimating $\mathrm{N}_{2} \mathrm{O}$ emissions from agricultural soils is important to avoid overestimating the $\mathrm{N}$ emitted (e.g., $\mathrm{NO}_{x}$ and $\mathrm{N}_{2}$, which are also produced through nitrification and denitrification processes). On the other hand, $\mathrm{N}_{2} \mathrm{O}$ emissions can also be underestimated, for example, due to the length of insufficient $\mathrm{N}_{2} \mathrm{O}$ measurements [18]. The consideration of impact factors in general is important to identify $\mathrm{N}_{2} \mathrm{O}$ emission hot spots and hot moments in a region and to identity $\mathrm{N}_{2} \mathrm{O}$ mitigation options.

Several papers have been published that classify and describe the main factors affecting $\mathrm{N}_{2} \mathrm{O}$ emissions from agricultural sites [16,19-23]. For example, Stehfest and Bouwman [18] estimated global annual $\mathrm{N}_{2} \mathrm{O}$ emissions from agricultural fields and natural vegetation by considering factors such as soil $\mathrm{N}$ concentration, soil organic carbon (SOC) content, soil $\mathrm{pH}$ and texture, fertilizer types and length of $\mathrm{N}_{2} \mathrm{O}$ emissions measurement. Weier et al. [24] analyzed the impacts of soil water content, available $\mathrm{C}$ and $\mathrm{NO}_{3}{ }^{-}$concentration on denitrification in North America, as well as the $\mathrm{N}_{2} / \mathrm{N}_{2} \mathrm{O}$ ratio based on 
laboratory data. These laboratory data were also used by Parton et al. [25] to develop semiempirical equations for developing an $\mathrm{N}_{2} \mathrm{O}$ emission model. In another study, Bouwman et al. [20] determined factors affecting $\mathrm{N}_{2} \mathrm{O}$ emissions and grouped them into environmental, management and measurement categories. These measurement factors are particularly important to contribute to the process of understanding $\mathrm{N}_{2} \mathrm{O}$ emissions and hence how they are represented in simulation models. Factors related to nitrification and denitrification processes have been reviewed by Cameron et al. [26], Oertel et al. [27], Signor et al. [17] and Ghimire et al. [28], while Saggar et al. [29] reviewed factors impacting denitrification and the $\mathrm{N}_{2} / \mathrm{N}_{2} \mathrm{O}$ ratio.

In this review we go beyond the current reviews; we review and summarize all of the relevant factors leading to $\mathrm{N}_{2} \mathrm{O}$ emissions, and we describe the impact of these factors on nitrification, denitrification and on $\mathrm{N}_{2} / \mathrm{N}_{2} \mathrm{O}$ partitioning. Furthermore, we identify the role of the impact factors in widely used $\mathrm{N}_{2} \mathrm{O}$ simulation models and their representation for simulating $\mathrm{N}_{2} \mathrm{O}$ effectively. Consideration of factors that influence $\mathrm{N}_{2} \mathrm{O}$ emissions is important for $\mathrm{N}_{2} \mathrm{O}$ modelling purposes, because ideally, by including as many impact factors in a model as possible, the uncertainties related to the simulation of $\mathrm{N}_{2} \mathrm{O}$ emissions may be reduced [25].

\section{Methods}

For this review, we performed a literature search for relevant peer-reviewed scientific papers using the SCOPUS searchable scientific database. Using the combined terms " $\mathrm{N}_{2} \mathrm{O}^{\prime}$ AND "agriculture" to search papers since 1990, we found more than 2000 published papers with the number of papers steadily increasing per year since 2005. In Figure 2, these papers are grouped into three groups: review related, research related, and model related. From these results, the review related papers were selected by using the terms " $\mathrm{N}_{2} \mathrm{O}$ ", $\mathrm{AND}$ "agriculture", with "factors" and "review" to report on factors that influence $\mathrm{N}_{2} \mathrm{O}$ emissions (Table S1). Research related papers for the environmental factors were selected by using the terms " $\mathrm{N}_{2} \mathrm{O}$ ", "nitrification", "denitrification", " $\mathrm{N}_{2} / \mathrm{N}_{2} \mathrm{O}$ ratio" and each impact factor respectively (e.g., "soil N", "SOC", "soil temperature"). Research related papers for the management and measurement factors were searched by using the terms " $\mathrm{N}_{2} \mathrm{O}$ ", "agriculture", "factors" and each factor respectively (e.g., "N fertilizer", "tillage"). We obtained the model related papers relevant to the simulation of nitrification and denitrification from the above researched papers. Finally, the specific model related papers were searched with the terms " $\mathrm{N}_{2} \mathrm{O}$ ", "agriculture", and the respective models "DAYCENT", "DNDC" or "SWAT". These three models were chosen because they are process-based models that dynamically respond to the impact factors we researched, they are widely used, and lastly are well documented in peer-reviewed literature.

This literature review firstly summarizes the empirical factors that influence $\mathrm{N}_{2} \mathrm{O}$ emissions from agricultural soils (Table S1). These factors are divided into three categories, as in Bouwman et al. [20]: environmental factors, management factors, and measurement factors. Measurement factors are not presented in the same depth as the environmental factors and management factors, because they do not directly influence $\mathrm{N}_{2} \mathrm{O}$ emissions, but are useful to compare to the model performance. We explain how each impact factor affects $\mathrm{N}_{2} \mathrm{O}$ emissions from the soil and also summarize their interactions. Secondly, the review describes three process-based simulation models that calculate $\mathrm{N}_{2} \mathrm{O}$ emissions and that are widely used for modelling agricultural systems. The process-based models include DAYCENT (Daily Century) [30], DNDC (DeNitrification-DeComposition) [31] and SWAT (Soil and Water Assessment Tool) [32]. We describe the most relevant formulas in the models for calculating $\mathrm{N}_{2} \mathrm{O}$ emissions. Each model contains process descriptions that consider different impact factors to describe $\mathrm{N}_{2} \mathrm{O}$ emissions from agricultural soils. We describe the factors in each model and how they are represented in the respective model. 


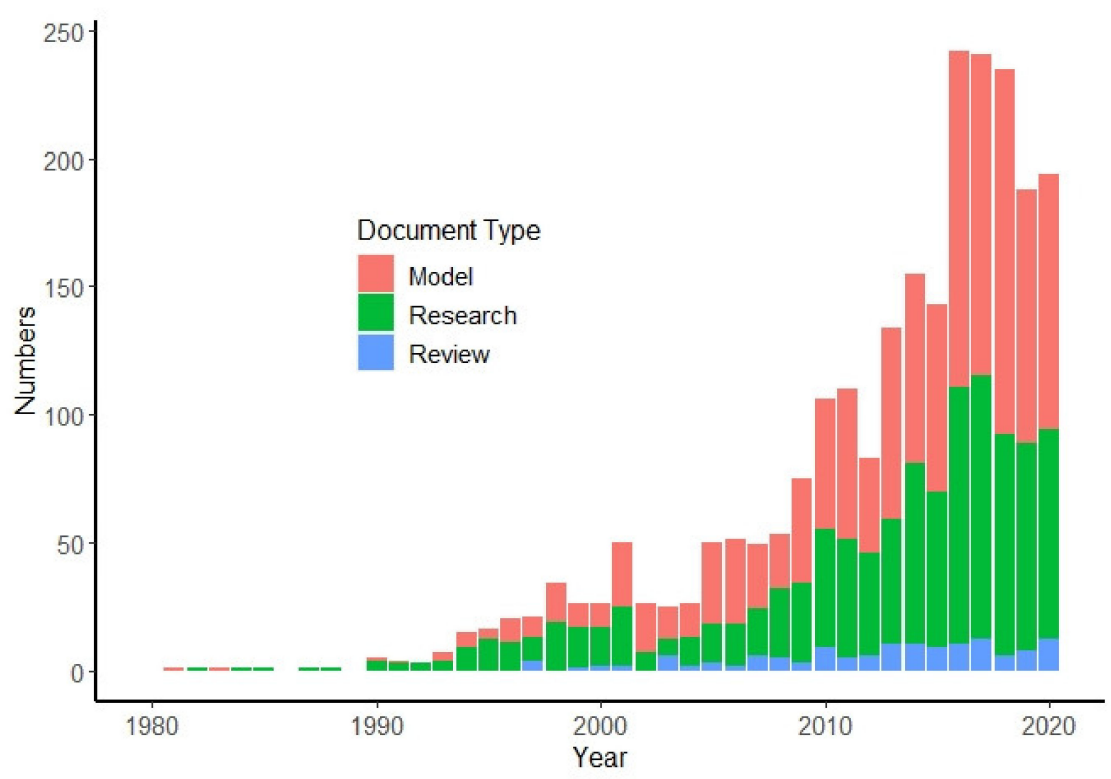

Figure 2. Peer-reviewed publications on $\mathrm{N}_{2} \mathrm{O}$ and agriculture since 1990 searched in the SCOPUS database.

\section{Factors That Influence Nitrous Oxide Emissions}

The subcategories environmental factors, management factors and measurement factors are listed in Table 1. Due to the spatial and temporal heterogeneity of the environment and the agricultural management practices reported, the threshold values at which nitrification and denitrification occur across various catchment characteristics are rather different $[12,29,33]$ and these are not reported in detail in this review. In the following sections, we provide a comprehensive explanation of how each impact factor affects $\mathrm{N}_{2} \mathrm{O}$ emissions from agricultural soils and we extract generalized relationships between each factor and $\mathrm{N}_{2} \mathrm{O}$ emissions.

Table 1. Impact factors that directly and indirectly influence $\mathrm{N}_{2} \mathrm{O}$ emissions from managed soils.

\begin{tabular}{ccc}
\hline Environmental Factors & Management Factors & Measurement Factors \\
\hline Microbial population & Fertilizer application & Length of measurement period \\
Soil available carbon & Tillage system & Types of measurements \\
Soil N concentration & Harvest and crop residues & \\
Soil moisture & Irrigation & \\
Soil texture & & \\
Soil temperature & & \\
Soil pH and salinity & & \\
\hline
\end{tabular}

\subsection{Environmental Factors}

Soil microbial populations that are responsible for nitrification and denitrification processes leading to $\mathrm{N}_{2} \mathrm{O}$ emission require specific environmental conditions. These conditions have been measured to directly influence the activities of certain microbes and lead to instantaneous changes in the rates of nitrification and denitrification and in the $\mathrm{N}_{2} / \mathrm{N}_{2} \mathrm{O}$ ratio [29]. The environmental factors that impact $\mathrm{N}_{2} \mathrm{O}$ emissions by influencing nitrification, denitrification and the $\mathrm{N}_{2} / \mathrm{N}_{2} \mathrm{O}$ ratio are described in this section.

\subsubsection{Microbial Populations}

Soil microorganisms are responsible for nitrification and denitrification processes [34,35]. Nitrification is primarily carried out by autotrophic bacteria (e.g., Nitrosomonas and Nitrobacter) [30]. Denitrification is carried out by microorganisms that include phototrophs, lithotrophs, and organotrophs that derive energy from light, inorganic $\mathrm{N}$, and organic $\mathrm{C}$, respectively. 
The dominant de-nitrifiers in soils are organotrophs, and species of Pseudomonas, which predominate in the group, presumably because of their versatility and ability to compete for $C$ substrates. Most of the other de-nitrifiers in soils are species of Alcaligenes, which are closely related to Pseudomonas $[16,36]$.

Soil microorganisms can also influence $\mathrm{N}_{2} \mathrm{O}$ emissions by affecting the $\mathrm{N}$ product ratio (e.g., $\mathrm{N}_{2} / \mathrm{N}_{2} \mathrm{O}$ ) of denitrification [34,35]. Chen et al. [37] isolated Pseudomonas denitrificans G1, which could remove $90 \%-98 \%$ of $\mathrm{NO}_{3}{ }^{-}$and $97 \%-99 \%$ of $\mathrm{NO}_{2}{ }^{-}$in $24 \mathrm{~h}$ under anaerobic conditions, in which Pseudomonas denitrificans G1 grew relatively slowly compared to under aerobic conditions, but could achieve effective denitrification so that the final product was $\mathrm{N}_{2}$.

Environmental impact factors also affect the distribution of soil microbes and microbial activity. For example, the suitable conditions for the denitrification of Pseudomonas denitrificans $\mathrm{G} 1$ to occur are a C/N ratio of 5-22, a dissolved oxygen of $0-4.68 \mathrm{mg} / \mathrm{L}$, a salinity of $0-30 \mathrm{~g} \mathrm{NaCl} / \mathrm{L}$, and a $\mathrm{pH}$ 7-9.5 [37].

\subsubsection{Soil Available Carbon}

The availability of soil $\mathrm{C}$ generally provides an energy source for soil microorganisms $[17,38]$ and hence increases microbial activity. Nitrifiers and denitrifiers require a readily available $\mathrm{C}$ source for the oxidation of ammonium $\left(\mathrm{NH}_{4}{ }^{+}\right)$and the reduction of $\mathrm{NO}_{3}{ }^{-}$. The capacity for soil nitrification and denitrification to take place increases with increasing SOC content, especially the water-soluble $\mathrm{C}$ content, because this is the source most readily available for microbes and leads to an increased microbial activity $[22,39,40]$. Chen et al. [41] investigated the influence of soil C on the $\mathrm{N}_{2} \mathrm{O}$ emissions from a paddy field in southern China and found the mass fraction of $\mathrm{N}_{2} \mathrm{O}$ in the total $\mathrm{N}$ gas emissions were $35 \%$ and $50 \%$ with $28 \mathrm{mg} \mathrm{kg}^{-1}$ and $300 \mathrm{mg} \mathrm{kg}^{-1}$ of soil organic C, respectively.

The amount of organic $\mathrm{C}$ as a substrate for bacteria will determine whether de-nitrifiers produce mostly $\mathrm{N}_{2}$ or $\mathrm{N}_{2} \mathrm{O}$ [42]. Weier et al. [24] analyzed the impacts of available carbon on the $\mathrm{N}_{2} / \mathrm{N}_{2} \mathrm{O}$ ratio emitted in a sand and silt loam soil in California with different treatment of glucose- $\mathrm{C}\left(0,0.5\right.$, and $1.0 \mathrm{mg}$ glucose- $\mathrm{C} \mathrm{g}{ }^{-1}$ soil). The largest $\mathrm{N}_{2} / \mathrm{N}_{2} \mathrm{O}$ ratio (up to 549) was found at the highest treatment of glucose-C (1.0 mg glucose- $\mathrm{C} \mathrm{g}^{-1}$ soil). The findings indicate that $\mathrm{SOC}$ could increase microbial activity and the consumption of $\mathrm{N}_{2} \mathrm{O}$, and other studies contain similar findings [43,44]. However, Saggar et al. [29] found, the impact of SOC on the $\mathrm{N}_{2} / \mathrm{N}_{2} \mathrm{O}$ ratio varies with soil $\mathrm{N}$, which is supported by Köster et al. [45], who investigated $\mathrm{N}_{2}$ and $\mathrm{N}_{2} \mathrm{O}$ emissions from soil with different $\mathrm{C} / \mathrm{N}$ ratio. The low $\mathrm{N}_{2} \mathrm{O}$ emissions could be attributed to the promoting effect of SOC input on $\mathrm{N}_{2} \mathrm{O}$ reduction when soil $\mathrm{N}$ is low.

Research with biochar suggest its suppression of $\mathrm{N}_{2} \mathrm{O}$ emissions from soil depends on the biochar-induced soil $\mathrm{C} / \mathrm{N}$ ratio, and potentially low subsequent soil $\mathrm{N}$ availability. Biochar is a carbon-rich material with a high $\mathrm{C} / \mathrm{N}$ ratio that is applied in some farming systems as a soil amendment. Due to biochar's high sorption capacity and elevated recalcitrance to biodegradation, it can be used to sequester carbon [46]. Feng et al. [47] studied the impact of biochar on $\mathrm{N}_{2} \mathrm{O}$ emissions from maize fields in China and found the $\mathrm{N}_{2} \mathrm{O}$ emissions decreased with increasing biochar application rates. Cumulative $\mathrm{N}_{2} \mathrm{O}$ emissions from soils with additions of $0.5 \%, 1 \%$, and $2 \%$ biochar were measured to be $120.9 \mathrm{~g} \mathrm{~N} / \mathrm{ha}, 61.7 \mathrm{~g} \mathrm{~N} / \mathrm{ha}$ and $47.6 \mathrm{~g} \mathrm{~N} /$ ha, respectively.

\subsubsection{Soil N Concentration}

All forms of $\mathrm{N}$ input into agricultural soils, such as inorganic $\mathrm{N}$ fertilizer, and organic $\mathrm{N}$ sources in the form of manures, slurry, legumes or post-harvest crop residues, represent a potential contribution to $\mathrm{N}$ substrates for $\mathrm{N}_{2} \mathrm{O}$ emissions $[16,48,49]$. During nitrification, $\mathrm{NH}_{4}{ }^{+}$is oxidized to $\mathrm{NO}_{3}{ }^{-}$. Thereafter the $\mathrm{NO}_{3}{ }^{-}$is reduced to $\mathrm{N}_{2} \mathrm{O}$ by denitrifying bacteria. The nitrate molecule is the primary requirement for denitrification to take place. Soil $\mathrm{NO}_{3}{ }^{-}$concentration is dynamic and at any given time depends on net mineralization and nitrification rates, the plant $\mathrm{N}$ uptake, the microbial immobilization rate and the $\mathrm{NO}_{3}{ }^{-}$ 
movement through the soil by leaching and lateral flow [26]. In the literature, it is agreed that the relationship between $\mathrm{N}$ input and nitrification is positive. However, the proportion of $\mathrm{N}_{2} \mathrm{O}$ emissions as nitrified $\mathrm{N}$ varies according to the soil type and climate [50].

Several studies show that high soil $\mathrm{NO}_{3}{ }^{-}$concentrations inhibit the reduction of $\mathrm{N}_{2} \mathrm{O}$ to $\mathrm{N}_{2}$ [42,51,52]. In sand and silt loam soils in California, Weier et al. [24] performed experiments to analyze the $\mathrm{N}_{2} / \mathrm{N}_{2} \mathrm{O}$ ratio as affected by different soil $\mathrm{NO}_{3}{ }^{-}$concentrations $\left(0,139\right.$, and $277 \mathrm{ug} \mathrm{KNO}_{3}-\mathrm{N} \mathrm{g}^{-1}$ soil), and found the highest soil $\mathrm{NO}_{3}{ }^{-}$concentration (277 ug $\mathrm{KNO}_{3}-\mathrm{N} \mathrm{g}^{-1}$ soil) inhibited $\mathrm{N}_{2} \mathrm{O}$ reductase activity, which reduced the conversion of $\mathrm{N}_{2} \mathrm{O}$ to $\mathrm{N}_{2}$ and resulted in a low $\mathrm{N}_{2} / \mathrm{N}_{2} \mathrm{O}$ ratio.

\subsubsection{Soil Moisture}

Almost all studies have reported increased $\mathrm{N}_{2} \mathrm{O}$ emissions after the application of $\mathrm{N}$ fertilizer, especially with high soil moisture. Furthermore, $\mathrm{N}_{2} \mathrm{O}$ is generally emitted most rapidly when the soil has $>60 \%$ water-filled-pore space (WFPS) [53-56]. The equations for calculating the WFPS are provided in the Supplementary Section (Equations (S3) and (S4)). When WFPS is greater than $60 \%$, the soil pore water displaces the amount of available $\mathrm{O}_{2}$ in the soil pores, and therefore leads to anaerobic soil moisture conditions, which are conductive to the production of $\mathrm{N}_{2} \mathrm{O}$. Under such conditions, the soil $\mathrm{NO}_{3}{ }^{-}$is reduced by facultative anaerobic bacteria (e.g., Pseudomonas citronellolis) to $\mathrm{NO}_{2}{ }^{-}, \mathrm{N}_{2} \mathrm{O}$ and then $\mathrm{N}_{2}[7,22,27,48]$. However, the optimum WFPS for nitrification and denitrification processes to occur varies with soil texture $[24,25]$.

Bateman et al. [53] studied $\mathrm{N}_{2} \mathrm{O}$ production during denitrification, autotrophic nitrification and heterotrophic nitrification in a fertilized (200 $\mathrm{kg} \mathrm{N}^{-1}$ ) silt loam soil in England with the WFPS ranging from 20\%-70\%. They found that at $70 \%$ WFPS all of the $\mathrm{N}_{2} \mathrm{O}$ emitted was through denitrification, but at 35\%-60\% WFPS nitrification was the main process producing $\mathrm{N}_{2} \mathrm{O}$. Ruser et al. [56] analyzed the impact of different soil moisture levels between $40 \%$ and $98 \%$ WFPS on $\mathrm{N}_{2} \mathrm{O}$ emissions from a fine-loamy soil in Germany. They found $\mathrm{N}_{2} \mathrm{O}$ emissions by denitrification increased when soil moisture rose above $60-70 \%$ WFPS.

The proportion of $\mathrm{N}_{2}$ gas $\left(\mathrm{N}_{2} / \mathrm{N}_{2} \mathrm{O}\right.$ ratio) during denitrification, however, is higher when the soil moisture is greater than $90 \%$, because $\mathrm{N}_{2} \mathrm{O}$ is consumed under anaerobic conditions [55-57]. Ciarlo et al. [54] analyzed the influence of different soil moisture contents on the ratio of $\mathrm{N}_{2} / \mathrm{N}_{2} \mathrm{O}$, which was emitted from a grassland in Argentina. The $\mathrm{N}_{2} \mathrm{O} /\left(\mathrm{N}_{2} \mathrm{O}+\mathrm{N}_{2}\right)$ ratio was low (0-0.051) under 120\% WFPS (with 100\% WFPS plus a 2-cm surface water layer) and increased with decreasing soil moisture, but was still above $60 \%$ WFPS. The greatest $\mathrm{N}_{2} \mathrm{O}$ emissions occurred at $80 \%$ WFPS treatment. Friedl et al. [55] investigated the influence of different soil moisture contents on $\mathrm{N}_{2}$ and $\mathrm{N}_{2} \mathrm{O}$ emissions from a subtropical dairy pasture in Australia. $\mathrm{N}_{2}$ emissions exceeded $\mathrm{N}_{2} \mathrm{O}$ emissions by a factor of 8 when the soil was at $80 \%$ WFPS and by a factor of 17 at $100 \%$ WFPS.

It is not surprising that $\mathrm{N}_{2} \mathrm{O}$ emissions are higher in wet environments, e.g., during seasons with higher precipitation and higher soil water contents. For example, Choudhary et al. [58] confirmed this in a study on permanent pastureland on silty clay loam soil in New Zealand during dry and wet seasons. In another study on grain sorghum and sunflower in sub-tropical Australia, Schwenke et al. [59] measured the rate of $\mathrm{N}_{2} \mathrm{O}$ loss to be five times greater during the wet season compared to the dry season. During the drier season, the ratio of $\mathrm{N}_{2} / \mathrm{N}_{2} \mathrm{O}$ was $43 \%$, whereas the ratio declined from $29 \%$ to $12 \%$ with increased $\mathrm{N}$ fertilizer rate during the wetter season.

The $\mathrm{N}_{2} \mathrm{O}$ emission factors are considered separately for dry and wet climates. In 2019, the IPCC revised the $\mathrm{N}_{2} \mathrm{O}$ EF so that in wet climates the default EF has been set at $0.6 \%$ of organic $\mathrm{N}$ inputs and $1.6 \%$ of synthetic $\mathrm{N}$ inputs. In dry climates, the default $\mathrm{EF}$ has been set at $0.5 \%$ of $\mathrm{N}$ for both organic and synthetic $\mathrm{N}$ applications [13]. 


\subsubsection{Soil Texture}

Finer textured soils can emit higher amounts of $\mathrm{N}_{2} \mathrm{O}$ than sandy soils [60]. They have more capillary pores within aggregates than sandy soils, thereby holding soil water more tightly [24,25]. As a result, anaerobic conditions may be potentially more easily reached and maintained for longer periods within aggregates in finer textured soils than in sandy soils [18,20]. Weier et al. [24] and Parton et al. [25] found that denitrification generally increased as soil texture became finer and as the WFPS increased. When the WFPS decreases, the denitrification rate decreases most rapidly in the fine-textured soils, followed by medium- and coarse- textured soils. The best fit curve (WFPS $/ \mathrm{N}_{2} \mathrm{O}$ emissions) for clay soils increases very rapidly as WFPS increases over $40 \%$ and reaches the highest emission value for WFPS greater than $70 \%$ [25].

Soil texture mainly affects $\mathrm{N}_{2} \mathrm{O}$ emissions by determining how likely it is for aerobic or anaerobic conditions in the soil to prevail $[21,60,61]$. Soil texture also affects $\mathrm{N}_{2} \mathrm{O}$ emissions due to differences in SOC, $\mathrm{N}$ availability, and microbial population [62].

Site exposure (e.g., elevation, morphological position, plant cover) can also influence soil temperature and moisture. $\mathrm{N}_{2} \mathrm{O}$ emissions are higher in depressions than on sloped land and ridges, due to the increased soil moisture content mostly found in low-lying lands. Yet lower air pressure found at higher elevation facilitates $\mathrm{N}_{2} \mathrm{O}$ emissions due to a reduced counter pressure on the soil $[27,48,63]$.

\subsubsection{Soil Temperature}

Soil temperature affects $\mathrm{N}_{2} \mathrm{O}$ emissions by directly influencing the kinetic reaction and the growth of microbial communities (e.g., Pseudomonas) $[7,16,19,60]$. Moreover, soil temperature controls biological oxygen consumption by altering the growth of microbial communities, which leads to a depletion of soil oxygen concentrations and an increase of anaerobic status in soil $[39,64]$.

In most studies, nitrification rates increase with rising temperature and the general peaks are around 20 to $35^{\circ} \mathrm{C}$ [25,30], even though Lai et al. [65] reported that the temperature peaks for nitrification were between 35 and $40^{\circ} \mathrm{C}$ and Prentice [66] reported the optimum temperature for nitrification to be $38^{\circ} \mathrm{C}$. Lai et al. [65] found that soil temperature variations have less impact on the proportion of $\mathrm{N}_{2} \mathrm{O}$ emissions from nitrified $\mathrm{N}$, when compared to the impact of variations in soil type [65].

Overall, studies show that nitrification and denitrification processes are similar with respect to temperature dependency and increase with increasing soil temperature, although Saggar et al. [29] found no relationship between denitrification rate and soil temperature. Peak denitrification occurs between 40 and $60{ }^{\circ} \mathrm{C}[22,65,67]$. It is worth noting that the temperature for peak nitrification and denitrification to occur may vary somewhat by climatic region [67].

Soil temperature also influences $\mathrm{N}_{2} \mathrm{O}$ emissions by affecting the ratio of $\mathrm{N}_{2} / \mathrm{N}_{2} \mathrm{O}[16,22,68,69]$. Maag et al. [70] found that $\mathrm{N}_{2} / \mathrm{N}_{2} \mathrm{O}$ increased exponentially with increasing temperature, which implies a linear relationship between the $\log \left(\mathrm{N}_{2} / \mathrm{N}_{2} \mathrm{O}\right)$ and temperature. Lai and Denton [67] analyzed $\mathrm{N}_{2} \mathrm{O}$ and $\mathrm{N}_{2}$ emissions from a dairy farm in southwest Australia with different temperature levels $\left(25^{\circ} \mathrm{C}, 35^{\circ} \mathrm{C}, 45^{\circ} \mathrm{C}\right)$. The highest rate of $\mathrm{N}_{2} \mathrm{O}$ emissions occurred at $35^{\circ} \mathrm{C}$. A decrease in $\mathrm{N}_{2} \mathrm{O}$ emissions above $35^{\circ} \mathrm{C}$ was partially attributed to an increase in $\mathrm{N}_{2} \mathrm{O}$ reduction and $\mathrm{N}_{2}$ production. Increased $\mathrm{N}_{2}$ production at $45^{\circ} \mathrm{C}$ decreased the $\mathrm{N}_{2} \mathrm{O} / \mathrm{N}_{2}$ ratio by $33 \%$ to $85 \%$. The literature strongly agrees that the reduction of $\mathrm{N}_{2} \mathrm{O}$ to $\mathrm{N}_{2}$ increases with increasing soil temperature.

Soil temperature also influences freeze-thaw cycles, which increase the availability and accessibility of the $\mathrm{N}$ in the soil and also create anaerobic conditions, and thus impact on the release of $\mathrm{N}_{2} \mathrm{O}$ and $\mathrm{N}_{2}[29,71]$. In some regions (e.g., in mid to higher latitudes and at higher elevations of the world), the topsoil is routinely frozen for parts of the winter and these soils can also be subject to successive freeze-thaw cycles. It has been determined that a substantial part of the total annual $\mathrm{N}_{2} \mathrm{O}$ emissions may occur within a brief period after thawing [59]. The principal cause is the development of conditions that stimulate 
anaerobic microbial activity, in particular the release of labile $\mathrm{C}$ and $\mathrm{N}$ compounds from dead microbial biomass, when soil-water content is high [49].

\subsubsection{Soil $\mathrm{pH}$ and Salinity}

Several studies show contradictory results when describing the impacts of soil $\mathrm{pH}$ on nitrification and denitrification. Clough et al. [72] examined the effect of raising the soil $\mathrm{pH}$ (through liming the soil) on $\mathrm{N}_{2} \mathrm{O}$ emissions from a silt loam. They found that autotrophic nitrification is limited at soil $\mathrm{Ph}<4.5$. Liming of acid soils can stimulate nitrification and has been shown to influence both the nitrification rate and the $\mathrm{N}_{2} \mathrm{O}$ flux. Denitrification rates decrease with decreasing soil $\mathrm{pH}$. Scholefield et al. [52] developed a "flow-over" helium atmosphere core incubation technique to investigate mechanisms of denitrification in agricultural soils. They found that denitrification decreased with increasing soil $\mathrm{pH}$ within the range 5.1-9.4. In a review of the past 50 years of studying the impact of soil pH on denitrification, Šimek and Cooper [73] stated that it is not possible to generalize the relationship between $\mathrm{pH}$ and denitrification in soils.

The soil $\mathrm{pH}$ also affects the emission ratio of $\mathrm{N}_{2} / \mathrm{N}_{2} \mathrm{O}$. It is well agreed that soil $\mathrm{pH}$ influences $\mathrm{N}_{2} \mathrm{O}$ emissions by affecting the activity of nitrifying and denitrifying bacteria in the soil $[22,27,60]$. The soil $\mathrm{pH}$ determines if $\mathrm{NO}_{2}{ }^{-}$and $\mathrm{NO}_{3}{ }^{-}$chemically decompose into $\mathrm{N}_{2} \mathrm{O}$ or into $\mathrm{N}_{2}$. Under acidic conditions $\mathrm{N}_{2} \mathrm{O}$ is emitted by denitrifier bacteria, such as Pseudomonas [42]. Therefore, a greater proportion of $\mathrm{N}_{2} \mathrm{O}$ relative to $\mathrm{N}_{2}$ is emitted from acidic soils $(\mathrm{pH}<6.0)$, whereas approximately equivalent amounts of $\mathrm{N}_{2} \mathrm{O}$ and $\mathrm{N}_{2}$ are emitted from soils with pH 6.0 [74]. This is confirmed by Šimek et al. [75], who found that at a $\mathrm{pH}<6.0$, the only denitrification product was $\mathrm{N}_{2} \mathrm{O}$, but at higher $\mathrm{pH}$ values, $\mathrm{N}_{2}$ was the principal product of denitrification. They examined five mineral soils with a similar texture but with differing $\mathrm{pHs}$ in Czech Republic. In soils in which the $\mathrm{pH}$ was 8.3-8.5, the $\mathrm{N}_{2} \mathrm{O} / \mathrm{N}_{2}$ mole fraction was found to be about 0.024 from grey clay soils with irrigated cotton in Australia [74].

Soil salinity influences the production and consumption of $\mathrm{N}_{2} \mathrm{O}$ [76]. Wei et al. [77] conducted an experiment on a silty clay soils used to grow vegetables in China, and analyzed the impacts of different salinity levels $(2,5,8 \mathrm{~g} / \mathrm{L})\left(\mathrm{NaCl}\right.$ and $\mathrm{CaCl}_{2}$ of $1,2.5$, and $4 \mathrm{~g} / \mathrm{L}$ equivalent) and fertilizer levels on $\mathrm{N}_{2} \mathrm{O}$ emissions. Compared to fresh water irrigated soil, cumulative $\mathrm{N}_{2} \mathrm{O}$ fluxes were reduced by $22.7 \%$ and $39.6 \%$ ( $0 \mathrm{~kg} \mathrm{~N}$ fertilizer), and $29.1 \%$ and $39.2 \%$ (120 kg N fertilizer) for soils irrigated with 2 and $8 \mathrm{~g} / \mathrm{L}$ saline water, respectively. For soils irrigated with $5 \mathrm{~g} / \mathrm{L}$ saline water, cumulative $\mathrm{N}_{2} \mathrm{O}$ fluxes were increased by $87.7 \%$ $(0 \mathrm{~kg} \mathrm{~N}$ fertilizer) and $58.3 \%$ (120 kg N fertilizer). These results suggest that desalinating brackish water to a low salinity level (e.g., $2 \mathrm{~g} / \mathrm{L}$ ) before it is used for irrigation, might be helpful for mitigating soil $\mathrm{N}_{2} \mathrm{O}$ emissions.

Based on the above literature, we extracted generalized relationships between each environmental factor and $\mathrm{N}_{2} \mathrm{O}$ emissions in Table 2.

Table 2. The relationships between environmental factors and $\mathrm{N}_{2} \mathrm{O}$ emissions.

\begin{tabular}{|c|c|c|c|c|c|}
\hline Processes & Soil N & SOC & $\begin{array}{c}\text { Soil Moisture } \\
\text { (Water-Filled-Pore-Space } \\
\text { (WFPS)) }\end{array}$ & Soil Temperature & Soil pH \\
\hline Nitrification & + & + & $\sim 60 \%:+$ & + & Need more research \\
\hline Denitrification & + & + & $60-80 \%:+$ & + & Need more research \\
\hline $\mathrm{N}_{2} / \mathrm{N}_{2} \mathrm{O}$ ratio & - & $+($ depends on $\mathrm{N})$ & $>90 \%:+$ & + & $\begin{array}{l}<6.0: \text { more } \mathrm{N}_{2} \mathrm{O} \\
=6.0: \text { equivalent; } \\
>6.0: \text { more } \mathrm{N}_{2}\end{array}$ \\
\hline
\end{tabular}




\subsection{Management Factors}

The type of field management plays an important role in influencing $\mathrm{N}_{2} \mathrm{O}$ emissions, especially as it determines the soil $\mathrm{N}$ input and thereby potentially changes the soil environmental and subsequent microbial conditions. Management factors include, for example, the amounts and the types of fertilizer application, the crops planted, and tillage operations undertaken, which also affect how much crop residues are left on the surface. This section provides a detailed description of how selected agricultural management operations influence $\mathrm{N}_{2} \mathrm{O}$ emissions.

\subsubsection{Fertilizer Application}

The influence of fertilizer on $\mathrm{N}_{2} \mathrm{O}$ emissions is related to the fertilizer type, the amount and the timing of application [59,78-80]. Nitrogen fertilizer types include synthetic (mineral) fertilizers (e.g., urea, ammonium nitrate, ammonium sulfate and NPK compound fertilizers, including slow-release fertilizers), solid organic fertilizer (e.g., organic manure, composted municipal soil waste, composted animal manure, and residues of crops), and liquid organic fertilizer (e.g., raw and digested pig slurries).

In the IPCC Refinement to the $\mathrm{N}_{2} \mathrm{O}$ Guidelines, the aggregated $\mathrm{N}_{2} \mathrm{O}$ EF is set at $1 \%$ of the amount of $\mathrm{N}$ applied to soils [13]. In the literature, several $\mathrm{EF}$ values have been measured [81] and Table 3 shows the breadth of $\mathrm{N}_{2} \mathrm{O}$ EF values reported for selected crops grown in various countries and on differing soils.

Table 3. The emission factor (EF) for $\mathrm{N}_{2} \mathrm{O}$ as reported in the literature.

\begin{tabular}{|c|c|c|c|c|c|c|}
\hline Source & Crops & $\mathrm{EF}(\%)$ & Country & Fertilizer Type & Soil Type & N Fertilizer (kg/ha) \\
\hline Rochester et al. [74] & Cotton & 1.1 & Australia & Mineral N & Clay & 180 \\
\hline \multirow{2}{*}{ Dechow et al. [82] } & Grassland & 0.92 & Germany & Mineral N & & 100 \\
\hline & Cropland & 0.9 & Germany & Mineral N & & $0-225$ \\
\hline Hoben et al. [83] & Corn & $0.6-1.5$ & USA & Mineral N & Loam & $0-225$ \\
\hline \multirow{2}{*}{ Lesschen et al. [60] } & Grassland & 1.1 & Europe & Mineral N & & $300-400$ \\
\hline & Grassland & 0.83 & Netherlands & Organic N & & \\
\hline Cheng et al. [84] & Corn & 0.34 & China & Mineral N & Sand & 266 \\
\hline de Morais et al. [85] & Grassland & 0.51 & Brazil & Mineral N & Clay & $80 / 100$ \\
\hline Pal et al. [86] & Pasture & 1.2 & New Zealand & Organic N & Clay loam & 213 \\
\hline \multirow{2}{*}{ Gao et al. [87] } & Winter wheat & 0.17 & China & Mineral N & Silty loam & 300 \\
\hline & Corn & 0.53 & China & Mineral N & Silty loam & 250 \\
\hline Lebender et al. [88] & Winter wheat & 0.46 & Germany & Mineral N & & \\
\hline \multirow{2}{*}{ Shi et al. [89] } & Corn & 0.42 & China & Mineral N & Sandy loam & 300 \\
\hline & Corn & 0.29 & China & Mineral N & Sandy loam & 186 \\
\hline \multirow{2}{*}{ Sordi et al. [90] } & Pasture & 0.15 & Brazil & Organic N & Clay & \\
\hline & Pasture & 0.26 & Brazil & Organic N & Clay & \\
\hline \multirow{2}{*}{ Zhang et al. [91] } & Corn & 2.5 & China & Mineral N & Clay & 173 \\
\hline & Winter wheat & 2 & China & Mineral N & Clay & 165 \\
\hline \multirow{4}{*}{ Aita et al. [92] } & Corn & 1.39 & Brazil & Mineral N & Loam & 130 \\
\hline & Corn & 1.18 & Brazil & Organic $\mathrm{N}$ & Loam & 333 \\
\hline & Winter wheat & 1.14 & Brazil & Mineral N & Loam & 110 \\
\hline & Winter wheat & 1.55 & Brazil & Organic N & Loam & 269 \\
\hline Hinton et al. [93] & Spring barley & 1.35 & UK & Mineral N & Sandy loam & 120 \\
\hline Huérfano et al. [94] & Winter wheat & 0.21 & Spain & Mineral N & Clay loam & 180 \\
\hline Martins et al. [95] & Corn & 0.2 & Brazil & Mineral N & Sandy loam & 120 \\
\hline \multirow{2}{*}{ Shepherd et al. [96] } & Corn & 1.4 & China & Mineral N & Clay & 150 \\
\hline & Wheat & 0.71 & China & Mineral N & Silty clay & 150 \\
\hline
\end{tabular}


Table 3. Cont.

\begin{tabular}{|c|c|c|c|c|c|c|}
\hline Source & Crops & EF (\%) & Country & Fertilizer Type & Soil Type & N Fertilizer (kg/ha) \\
\hline & Wheat & 1 & China & Mineral N & Clay loam & 150 \\
\hline Bell et al. [78] & Grassland & $1.06-1.34$ & UK & Mineral N & Sandy loam & $80-320$ \\
\hline \multirow{2}{*}{ Van der Weerden et al. [97] } & Pasture & 0.6 & New Zealand & Mineral N & & 50 \\
\hline & Pasture & 0.3 & New Zealand & Organic N & & 101 \\
\hline Harty et al. [98] & Pasture & 1.49 & Ireland & Mineral N & $\begin{array}{c}\text { Clay/sandy } \\
\text { loam }\end{array}$ & 200 \\
\hline \multirow{2}{*}{ Krol et al. [99] } & Grassland & 0.31 & Ireland & Organic N & Sandy loam & 280 \\
\hline & Grassland & 1.18 & Ireland & Organic N & Sandy loam & 507 \\
\hline Macdonald et al. [100] & Sugarcane & 3 & Australia & Mineral N & Sandy loam & \\
\hline \multirow{2}{*}{ Roche et al. [101] } & Spring barley & 0.35 & Ireland & Mineral N & Loam & 150 \\
\hline & Spring barley & 0.27 & Ireland & Mineral N & Loam & \\
\hline Faubert et al. [102] & Spring barley & $0.8-3.1$ & Canada & Organic N & Clay loam & $90-120$ \\
\hline Forte et al. [103] & Corn & 0.55 & Italy & Mineral N & $\begin{array}{l}\text { Sandy-clay- } \\
\text { loam }\end{array}$ & 130 \\
\hline \multirow{2}{*}{ Gillette et al. [104] } & Corn & 0.66 & USA & Mineral N & Clay loam & 224 \\
\hline & Corn & 0.75 & USA & Mineral N & Clay loam & 246 \\
\hline Htun et al. [105] & Winter wheat & 0.43 & China & Mineral N & Silty loam & 220 \\
\hline Laville et al. [106] & Corn & 1.8 & Italy & Mineral N & Sandy loam & 170 \\
\hline \multirow{2}{*}{ Krauss et al. [107] } & Winter wheat & 1.64 & Switzerland & Organic N & Clay & \\
\hline & Grassland & 0.71 & Switzerland & Organic N & & \\
\hline Pugesgaard et al. [108] & Spring barley & 0.65 & Denmark & Organic N & Sandy loam & 150 \\
\hline Xie et al. [109] & Apple orchard & 1.34 & China & Organic N & Sand & \\
\hline Zhou et al. [110] & Wheat & 1.05 & China & Mineral N & Loam & $0-250$ \\
\hline Badagliacca et al. [111] & Winter wheat & $\sim 1.9$ & Italy & Mineral N & Clay & 120 \\
\hline Dong et al. [112] & Corn & 0.308 & China & Mineral N & Clay & 180 \\
\hline Plaza-Bonilla et al. [113] & Winter wheat & $\sim 0.57$ & Spain & Mineral N & Loam & $0-120$ \\
\hline \multirow{2}{*}{ Reinsch et al. [114] } & Grassland & 0.27 & Germany & Organic N & Sandy loam & 180 \\
\hline & Corn & 0.74 & Germany & Organic N & Sandy loam & 180 \\
\hline \multirow{2}{*}{ Simon et al. [115] } & Pasture & 0.34 & Brazil & Organic $\mathrm{N}$ & Clay & 516 \\
\hline & Pasture & 0.11 & Brazil & Organic N & Clay & \\
\hline Campanha et al. [116] & Corn & 0.96 & Brazil & Mineral N & Clay & $0-275$ \\
\hline Kasper et al. [117] & Corn & 0.71 & Austria & Mineral N & Clay loam & \\
\hline Mumford et al. [118] & Pasture & $0.49-1.17$ & Australia & Mineral N & Clay & 340 \\
\hline \multirow{2}{*}{ Myrgiotis et al. [119] } & Winter wheat & 0.25 & UK & Mineral N & & \\
\hline & Spring barley & 0.57 & UK & Mineral N & & \\
\hline Shen et al. [120] & Spring barley & $0.085-1.1$ & Canada & Organic $\mathrm{N}$ & Clay loam & $100-800$ \\
\hline \multirow{2}{*}{ Zhang et al. [121] } & Winter wheat & $0.19-0.25$ & China & Mineral N & Loam & $420 / 600$ \\
\hline & Corn & $0.38-0.63$ & China & Mineral N & Loam & \\
\hline Baral et al. [122] & Spring barley & 0.53 & Denmark & Mineral N & Sand & 169 \\
\hline Cowan et al. [123] & Grassland & 0.9 & UK & Mineral N & Clay & $20-220$ \\
\hline Krol et a. [124] & Grassland & 0.58 & Ireland & Mineral N & Loam & 200 \\
\hline Kudeyarov et al. [125] & Cereal crops & $0.66-0.7$ & Russia & Mineral N & & 67 \\
\hline Wang et al. [126] & Corn & 1.85 & China & Mineral N & Clay loam & 130 \\
\hline Pareja-Sanchez et al. [127] & Corn & 0.2 & Spain & Mineral N & Sandy loam & $0 / 60 / 120$ \\
\hline Yang et al. [128] & Winter wheat & 0.41 & China & Mineral N & Silty loam & 220 \\
\hline
\end{tabular}

The blank cells in the soil type and $\mathrm{N}$ fertilizer columns indicate that the EFs are the average value of different soil types and $\mathrm{N}$ fertilizer application. The EFs are mean values for the range of $\mathrm{N}$ fertilizer. 
The fertilizers influence the mass of $\mathrm{N}_{2} \mathrm{O}$ emissions mainly because of the different amounts of $\mathrm{NH}_{4}{ }^{+}, \mathrm{NO}_{3}{ }^{-}$and organic $\mathrm{C}$ contained in them. Grave et al. [129] conducted experiments to determine the effects of the $\mathrm{N}$ sources on soil $\mathrm{N}_{2} \mathrm{O}$ emissions from a maizewheat rotation field in Brazil. Compared to the control experiment, cumulative $\mathrm{N}_{2} \mathrm{O}$ emissions from urea and slurry in tilled soil increased by $33 \%$ and $46 \%$, respectively. The EFs of $\mathrm{N}_{2} \mathrm{O}$ calculated with the application of urea and slurry were $0.27 \%$ and $0.76 \%$. Chen et al. [130] studied the impact of 13 years of nitrogen fertilization on $\mathrm{N}_{2} \mathrm{O}$ emissions from temperate grassland in northeast China, and found that the soil temperature, soil water contents, SOC and soil $\mathrm{NH}_{4}{ }^{+}$were greatly changed during the growing season, when a significant cumulative effect of fertilizer $\mathrm{N}$ addition on $\mathrm{N}_{2} \mathrm{O}$ emissions was measured.

The amounts of fertilizer applied add a source of $\mathrm{N}$ to the soil, which contributes to $\mathrm{N}_{2} \mathrm{O}$ emissions. Bordoloi et al. [131] analyzed $\mathrm{N}_{2} \mathrm{O}$ emissions from an Indian wheat cropping system under different levels of urea (from 0 to $100 \mathrm{~kg} \mathrm{~N}^{-1}$ ). Fertilized plots had higher $\mathrm{N}_{2} \mathrm{O}$ emissions than unfertilized plots by an average of up to $174 \%$ measured in the highest fertilized treatment with $100 \mathrm{~kg} \mathrm{~N} / \mathrm{ha}$, and in which the $\mathrm{N}_{2} \mathrm{O}$ EF was 3.15\%. Lebender et al. [88] conducted an experiment to analyze the impact of fertilizer application rates on $\mathrm{N}_{2} \mathrm{O}$ emissions from winter wheat in north-west Germany. Nitrogen was applied as calcium-ammonium-nitrate, with application rates ranging between 0 and $400 \mathrm{~kg} \mathrm{~N} \mathrm{ha}^{-1}$. Over a one-year period, yield-scaled $\mathrm{N}_{2} \mathrm{O}$ emissions from the $400 \mathrm{~kg} \mathrm{~N}^{-1}$ treatment were twice as high as from the $220 \mathrm{~kg} \mathrm{~N} \mathrm{ha}^{-1}$ treatment. The $\mathrm{N}_{2} \mathrm{O}$ EFs ranged between $0.46 \%$ and $0.53 \%$.

The time of fertilizer application influences the efficiency of fertilizer use and crop yields. Schwenke et al. [132] investigated the impacts of the timing of $\mathrm{N}$ fertilizer application on $\mathrm{N}_{2} \mathrm{O}$ emissions from grain sorghum field in Australia. Compared to urea applied at sowing, delayed application of urea at booting reduced the $\mathrm{N}_{2} \mathrm{O}$ emissions by $67 \%-81 \%$. However, crop $\mathrm{N}$ uptake, grain yield and protein content tended to be lower due to dry soil conditions during the mid-season. Applying split-N (33\% sowing; 67\% booting) using urea reduced $\mathrm{N}_{2} \mathrm{O}$ emissions by $59 \%$ compared to urea applied at the time of sowing, but maintained crop $\mathrm{N}$ uptake, grain yield and protein content. When mineral fertilizer or manure are applied before or at sowing, $\mathrm{N}_{2} \mathrm{O}$ emissions can increase because of the large pool of soil $\mathrm{N}$ in the early crop growth stages that cannot be assimilated by the crop, and furthermore $\mathrm{N}_{2} \mathrm{O}$ can be enhanced because of potential rainfall events, which increase the soil moisture [132].

\subsubsection{Tillage Systems}

Soil tillage results in changes in the soil structure, soil aeration, microbial activity, rate of residue decomposition and loss of soil organic matter from the system, as well as soil temperature and moisture $[127,133]$. It was also found that the presence or absence of tillage, the tillage period and tillage implements had an influence on $\mathrm{N}_{2} \mathrm{O}$ emissions [131,134].

Grave et al. [129] studied the effects of tillage practices on $\mathrm{N}_{2} \mathrm{O}$ emissions from a maizewheat rotation field in Brazil. Cumulative $\mathrm{N}_{2} \mathrm{O}$ emissions were $107 \%$ higher when $\mathrm{N}$ was applied on the no-till soil in comparison with the tilled soil. Higher $\mathrm{N}_{2} \mathrm{O}$ emissions were measured from no-till soil in response to increased WFPS $(>60 \%)$ and higher $\mathrm{N}$ availability (C/N around 1.58) compared with tilled soil [133]. Grass is a perennial monocotyledon plant that has a longer growing season and denser rooting system than annual crops. As such, $\mathrm{N}$ applied to grassland is rapidly (within a few days or weeks) taken up by the grass or immobilized in the rooting system $[20,60]$. Due to the absence of soil tillage in grasslands (soil aeration status), in combination with high $\mathrm{C}$ input by grass roots and residues and manure, the organic $C$ content of grasslands is higher than in arable cropping systems [135].

From a vegetable field in the USA, Chen et al. [37] measured the impacts of strip till, no-till, tillage with black plastic mulch and bare-ground on $\mathrm{N}_{2} \mathrm{O}$ emissions, whereby the yield-scaled $\mathrm{N}_{2} \mathrm{O}$ emissions were $4.21 \%, 3.18 \%, 10.17 \%, 5.57 \%$, respectively. Tillage with black plastic mulch promoted $\mathrm{N}$ mineralization, and the plastic mulch was found to increase the soil temperature, which contributed to greater $\mathrm{N}_{2} \mathrm{O}$ fluxes. 
Choudhary et al. [58] evaluated the effects of continuous long-term tillage on $\mathrm{N}_{2} \mathrm{O}$ emissions from maize fields in New Zealand. Average annual $\mathrm{N}_{2} \mathrm{O}$ emissions from the 34-year and 17-year fields were 2.37 and $3.42 \mathrm{~kg} \mathrm{~N}_{2} \mathrm{O} \mathrm{ha}^{-1}$, respectively. In the 34-year plots, due to continuous intensive cropping, low surface residue cover and a decreased water holding capacity, the depleted total $\mathrm{C}$ and $\mathrm{N}$ content were found to be low, which may have limited the denitrification process.

\subsubsection{Harvest and Crop Residues}

Applying crop residues to the soil generally increases $\mathrm{N}_{2} \mathrm{O}$ production mainly because the increased available organic $C$ can be used in the $\mathrm{N}$ mineralization processes $[108,136,137]$. In addition, crop residues decomposition requires aerobic conditions, following which the drawdown of soil oxygen activates denitrification [44]. Badagliacca et al. [138] investigated the addition of wheat and fava bean residues on $\mathrm{N}_{2} \mathrm{O}$ emissions from two soils. In the clay soil with low-soil organic $\mathrm{C}(2.4 \%)$ and high $\mathrm{pH}(8.1), \mathrm{N}_{2} \mathrm{O}$ emissions from fava bean residue-added pots were $0.81 \mathrm{~kg} \mathrm{ha}^{-1}$ and from pots added with wheat were $0.67 \mathrm{~kg} \mathrm{ha}^{-1}$. In the sandy-loam soil with high organic $\mathrm{C}(4.3 \%)$ and low $\mathrm{pH}(6.6), \mathrm{N}_{2} \mathrm{O}$ emissions in the pots added with wheat residue were $15.98 \mathrm{~kg} \mathrm{ha}^{-1}$ and that of the pots added with fava bean was $12.7 \mathrm{~kg} \mathrm{~N}_{2} \mathrm{O} \mathrm{ha}^{-1}$.

Different crop harvesting frequencies and intensities influence the proportions of dead material that are left on the surface of the soil, which affect $C$ and $N$ cycling due to the biochemical composition (e.g., $\mathrm{N}$ concentration in plant tissues) and subsequently influence the soil microbial population and diversity [16]. Liu et al. [139] analyzed the impact of harvesting reeds on the $\mathrm{N}_{2} \mathrm{O}$ emissions from alkaline wetlands in northeast China. The annual average $\mathrm{N}_{2} \mathrm{O}$ flux on plots without harvesting was two times higher than that of the harvested plots, because the harvesting of reeds decreased the total organic $\mathrm{C}$ and total $\mathrm{N}$. Da Silva et al. [140] studied how grazing intensity (light, moderate and heavy, i.e., $35 \mathrm{~cm}, 25$ $\mathrm{cm}$, and $15 \mathrm{~cm}$ height of grass, respectively) affects $\mathrm{N}_{2} \mathrm{O}$ emissions in grasslands in Brazil. Grazing intensity had a negative linear effect on annual cumulative $\mathrm{N}_{2} \mathrm{O}$ emissions.

\subsubsection{Irrigation}

Irrigation can include rain fed systems, high-watered systems (furrow, sprinkler and micro-sprinkler irrigation), and low-watered systems (surface and subsurface drip irrigation techniques). Irrigation influences the denitrification process by changing soil moisture and temperature, providing anaerobic conditions, and altering soil salinity [141-143]. An increase in WFPS may lead to reduced soil aeration resulting in low oxygen concentrations and anaerobic conditions, which support denitrification. An increased soil microbial activity may also lead to a decrease in the soil oxygen concentration $[59,143]$. The altered environmental factors could collectively affect dissolution/crystallization, oxidation/reduction, adsorption/desorption and other reactions that will finally change the production and consumption of $\mathrm{N}_{2} \mathrm{O}$ in the soil [19].

Sanchez-Martin et al. [144] carried out a field experiment to compare the difference between different irrigation systems on $\mathrm{N}_{2} \mathrm{O}$ emissions. They found that drip irrigation reduced total $\mathrm{N}_{2} \mathrm{O}$ emissions with respect to values for furrow irrigation. Tang et al. [145] studied the effects of irrigation regime on $\mathrm{N}_{2} \mathrm{O}$ emissions from a saline alkaline paddy field in northeast China. Continuous flooding irrigation kept the water depth on the soil at 3 to $5 \mathrm{~cm}$. The main difference in $\mathrm{N}_{2} \mathrm{O}$ emissions was during the mature stage, in which continuous flooding emitted twice as much $\mathrm{N}_{2} \mathrm{O}$ compared to intermittent flooding. Ye et al. [146] analyzed the impact of irrigation methods on $\mathrm{N}_{2} \mathrm{O}$ emissions from vegetable soils in China. Compared to conventional furrow irrigation, $\mathrm{N}_{2} \mathrm{O}$ emissions from mulched drip irrigation and drip filtration irrigation decreased by $16.4 \%$ and $60.9 \%$, respectively.

\subsection{Measurement Factors}

The measurement factors do not directly influence $\mathrm{N}_{2} \mathrm{O}$ emissions (although disturbance of natural conditions may occur when taking a sample, e.g., with chambers). However, the measurements are important factors to report because they affect the accuracy of the measured $\mathrm{N}_{2} \mathrm{O}$ amount and are useful for reporting on the uncertainties 
of the $\mathrm{N}_{2} \mathrm{O}$ measurements. The $\mathrm{N}_{2} \mathrm{O}$ measurements are a link to our understanding of what happens in the soil and what can be modelled. The measurements therefore also influence various modelling stages (e.g., model development, parameter optimization and model validation). The effect of insufficient $\mathrm{N}_{2} \mathrm{O}$ sample measurements from the soil either spatially or temporally can lead to an overestimation or to an underestimation of $\mathrm{N}_{2} \mathrm{O}$ emissions $[18,147]$. The main factors that contribute to measurement uncertainties are the methods applied for measuring $\mathrm{N}_{2} \mathrm{O}$ emissions and the temporal and spatial scales of measurement [148-151].

\subsubsection{Length of Measurement Period}

Establishing a regionally-specific EF usually requires the measurement of a whole year of $\mathrm{N}_{2} \mathrm{O}$ emissions [20]. Shang et al. [147] reviewed 21 studies including $\mathrm{N}_{2} \mathrm{O}$ emissions measured both during the whole-year and during the growing-season. For most crop types, the whole year EF was significantly greater than the growing season EF. Vegetables showed the largest EF difference $(0.19 \%)$ among all crops $(0.07 \%)$, followed by paddy rice $(0.11 \%)$. Neglecting to account for emissions from the non-growing season may underestimate the $\mathrm{N}_{2} \mathrm{O}$ emission factor by $30 \%$ for paddy fields, and almost three times that for non-vegetable upland crops.

Obtaining too few samples was highlighted in a study by Smith [142], who reviewed the relationship between the period length (days) of $\mathrm{N}_{2} \mathrm{O}$ being sampled to estimate $\mathrm{N}_{2} \mathrm{O}$ emissions from agricultural land, and found $\mathrm{N}_{2} \mathrm{O}$ emissions (\% of $\mathrm{N}$ fertilizer applied) during three different lengths of measurement periods $(>30,>100,>200$ days) to be $0.6,1.1$ and 1.6, respectively.

\subsubsection{Types of Measurement}

Many methods are used to measure $\mathrm{N}_{2} \mathrm{O}$ emissions in terrestrial and aquatic environments, for example chamber methods, static core methods and micrometeorological techniques [148]. Chambers are widely used to study $\mathrm{N}_{2} \mathrm{O}$ fluxes spatially at different scales (e.g., landscape). The static core method is used locally to estimate potential $\mathrm{N}_{2} \mathrm{O}$ emissions from managed soils to capture nitrification and denitrification processes. Micrometeorological techniques are the preferred methods for measuring $\mathrm{N}_{2} \mathrm{O}$ fluxes on a landscape (field) scale $[149,150]$.

However, because of the high spatial and temporal variability of $\mathrm{N}_{2} \mathrm{O}$ emissions, each measuring method has advantages and disadvantages, even at small landscape units [22]. Chamber methods represent the most accessible techniques for measuring $\mathrm{N}_{2} \mathrm{O}$ fluxes when chambers are placed on the soil surface for short periods. Nitric oxide and $\mathrm{N}_{2} \mathrm{O}$ fluxes can be measured using open- and closed- chamber techniques [150]. The flow rate of air through the open chamber can be too high to measure differences directly between the $\mathrm{N}_{2} \mathrm{O}$ concentrations in the air streams entering and leaving the chamber, and sometimes the closed chamber is only suitable for short height crops. Micrometeorological methods have to some extent been used to measure $\mathrm{N}_{2} \mathrm{O}$ emissions from the soil, and have the advantage over chambers in terms of their spatial and temporal integration [22]. Schäfer et al. [151] reported higher $\mathrm{N}_{2} \mathrm{O}$ emissions measured by closed chambers than by micrometeorological field-scale methods. In addition, when $\mathrm{N}_{2} \mathrm{O}$ emissions are measured at the hourly time step and at small spatial scale and then upscaled to the daily time step and the field scale, $\mathrm{N}_{2} \mathrm{O}$ fluxes may be overestimated $[119,151]$.

The uncertainties of measured $\mathrm{N}_{2} \mathrm{O}$ emissions are also high [151,152]. Schäfer et al. [151] reported the impacts of daily meteorological conditions on $\mathrm{N}_{2} \mathrm{O}$ measurement and concluded that all measurements should run from about sunset throughout the night when the atmosphere is usually more stable. Venterea [152] reported the differences of measured $\mathrm{N}_{2} \mathrm{O}$ emissions from three chambers in the same field ranging from 0.05 to $0.5 \mathrm{mg} \mathrm{N} \mathrm{m}^{-3}$. These three chambers have slightly different soil bulk density, water content, temperature and $\mathrm{pH}$. 
For further information on a review of the strengths and weaknesses of the $\mathrm{N}_{2} \mathrm{O}$ measurement methods, the reader is referred to Groffman et al. [148,153].

\subsection{Summary of Factors}

In this section, the factors' interactions within and between each group are depicted, to show how the three groups are connected, which is important when modelling $\mathrm{N}_{2} \mathrm{O}$ emissions. Figure 3 shows the factors' interactions within and between each group. Crops determine the amounts of $\mathrm{N}$ fertilizer application, irrigation, harvest frequencies and intensities, and the amounts of crop residues. Fertilizer application influences soil microbial population, soil $\mathrm{N}$ concentration and soil $\mathrm{pH}$. Tillage systems influence kinds of soil microbial population, soil carbon, soil moisture, soil structure, and soil temperature. Harvest and crop residues influence soil C, soil N, soil moisture and soil $\mathrm{pH}$. Irrigation controls soil moisture and anaerobic conditions. Microbial population, which is affected by soil moisture, soil structure, soil $\mathrm{pH}$ and soil temperature, influences the soil C:N ratio by mineralization and immobilization. Soil structure influences soil moisture, soil temperature and soil $\mathrm{pH}$.

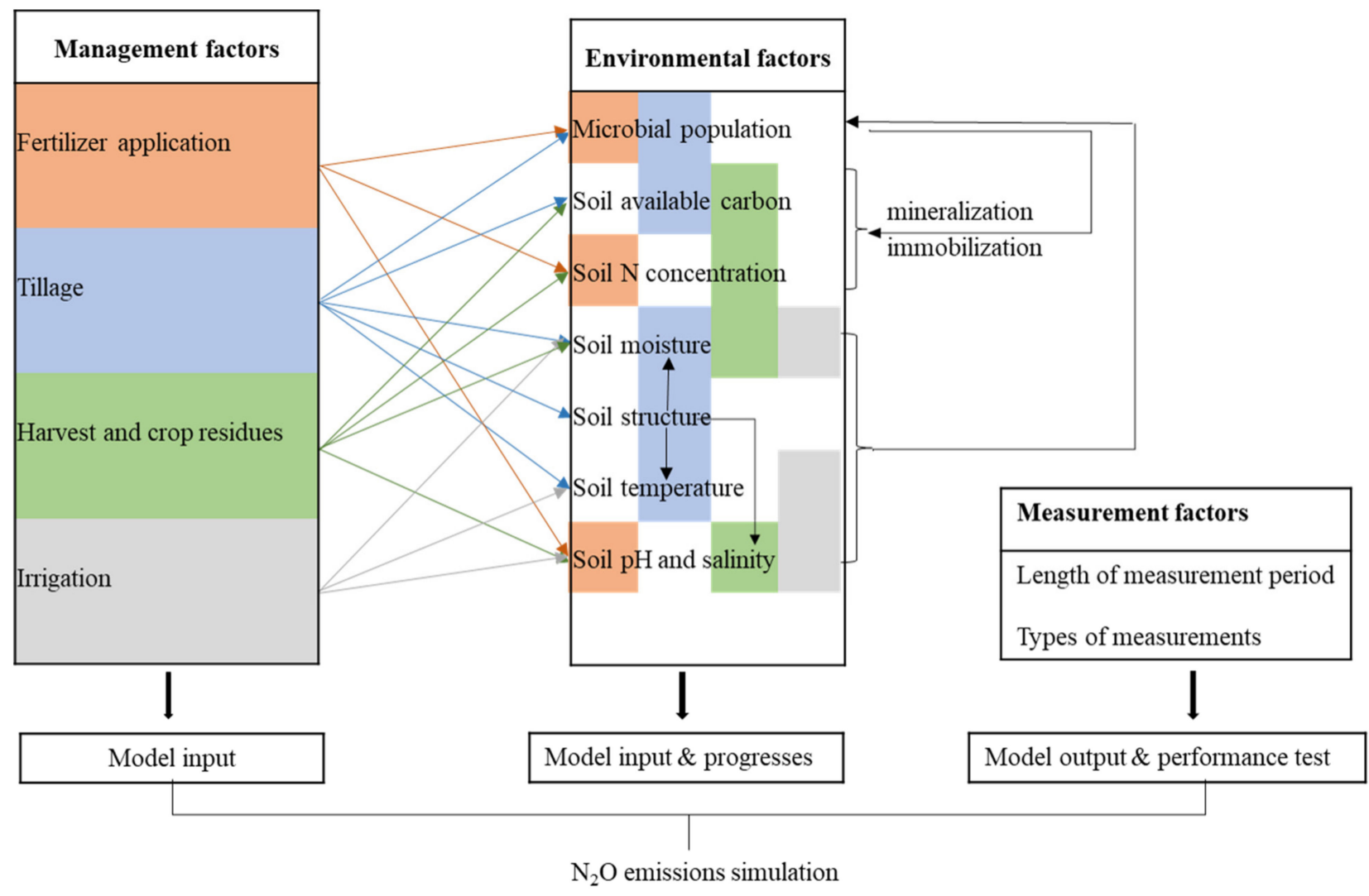

Figure 3. Schematic diagram of the impact factors on $\mathrm{N}_{2} \mathrm{O}$ emissions, their interactions, and how they may be considered in modelling $\mathrm{N}_{2} \mathrm{O}$ emissions. Color indicates which management factor affects which environmental factors.

Management factors can be considered as an input in terms of management practices into $\mathrm{N}_{2} \mathrm{O}$ simulation models. Environment factors are considered in a model either as model inputs (e.g., precipitation, air temperature, and soil properties), or as model internal processes (soil C, soil N, soil $\mathrm{pH}$, and soil temperature in model time step). Data from the measurement factors are extremely useful to test the model performance.

Process-based models used to estimate $\mathrm{N}_{2} \mathrm{O}$ emissions may include a single factor or several of the above described impact factors to simulate $\mathrm{N}_{2} \mathrm{O}$ emissions, all depending on the model's complexity and level of detail in the process-representation. Careful consideration of several important factors relevant to the research question at hand when estimating $\mathrm{N}_{2} \mathrm{O}$ emissions can avoid overestimation or underestimation of $\mathrm{N}_{2} \mathrm{O}$ amounts. 


\section{Current Process-Based Simulation Models}

A number of mathematical models have been developed to simulate nitrification and denitrification (Table 4) [154-167]. These models represent $\mathrm{N}_{2} \mathrm{O}$ emission processes to varying degrees, and each model has focused on one or several of the $\mathrm{N}_{2} \mathrm{O}$ impact factors outlined above, albeit to a different extent.

Table 4. Dynamic models used to simulate nitrification and denitrification in agricultural fields and the impact factors considered.

\begin{tabular}{|c|c|c|c|c|c|c|c|c|c|c|c|c|}
\hline \multirow{2}{*}{ Model } & \multirow{2}{*}{ Description } & \multicolumn{5}{|c|}{ Nitrification } & \multicolumn{5}{|c|}{ Denitrification } & \multirow{2}{*}{ Reference } \\
\hline & & $\mathbf{N}$ & SOC & WFPS & $\mathrm{T}$ & $\mathrm{pH}$ & $\mathbf{N}$ & SOC & WFPS & $T$ & $\mathrm{pH}$ & \\
\hline APEX & $\begin{array}{l}\text { APEX is a field-scale model and is used } \\
\text { to evaluate various land management } \\
\text { strategies at a daily time step. }\end{array}$ & $\sqrt{ }$ & & $\sqrt{ }$ & $\sqrt{ }$ & $\sqrt{ }$ & $\sqrt{ }$ & $\sqrt{ }$ & $\sqrt{ }$ & $\sqrt{ }$ & & $\begin{array}{l}\text { Williams et al. } \\
\text { [159] }\end{array}$ \\
\hline CERES_EGC & $\begin{array}{l}\text { CERES-EGC is a field-scale and } \\
\text { process-based agro-ecosystem model and } \\
\text { is used to simulate } \mathrm{NO}_{3}^{-} \text {leaching, } \\
\text { emissions of } \mathrm{N}_{2} \mathrm{O} \text { and nitrogen oxides at } \\
\text { a daily time step. }\end{array}$ & $\sqrt{ }$ & & $\sqrt{ }$ & $\sqrt{ }$ & & $\sqrt{ }$ & & $\sqrt{ }$ & $\sqrt{ }$ & & $\begin{array}{l}\text { Lehuger et al. } \\
\text { [160] }\end{array}$ \\
\hline $\begin{array}{l}\text { Daily Century } \\
\text { (DAYCENT) }\end{array}$ & $\begin{array}{l}\text { DAYCENT is the daily time step version } \\
\text { of the CENTURY, and is used to simulate } \\
\text { exchanges of C, nutrients, and trace gases } \\
\text { among the atmosphere, soil and plants. }\end{array}$ & $\sqrt{ }$ & & $\sqrt{ }$ & $\sqrt{ }$ & $\sqrt{ }$ & $\sqrt{ }$ & $\sqrt{ }$ & $\sqrt{ }$ & & & $\begin{array}{l}\text { Parton et al. } \\
\quad[30]\end{array}$ \\
\hline DNDC & $\begin{array}{l}\text { DNDC is a field-scale and process-based } \\
\text { model and is used to study } \mathrm{N} \text { and } \mathrm{C} \\
\text { dynamics in agroecosystems at daily } \\
\text { time step. }\end{array}$ & $\sqrt{ }$ & $\sqrt{ }$ & $\sqrt{ }$ & $\sqrt{ }$ & $\sqrt{ }$ & $\sqrt{ }$ & $\sqrt{ }$ & & $\sqrt{ }$ & $\sqrt{ }$ & Li et al. [31] \\
\hline $\begin{array}{l}\text { DRAINMOD-N } \\
\text { II }\end{array}$ & $\begin{array}{l}\text { DRAINMOD-N II is a field-scale, daily } \\
\text { time step and process-based model and } \\
\text { is used to simulate } C \text { and } N \text { dynamics for } \\
\text { artificially drained soils. }\end{array}$ & $\sqrt{ }$ & & $\sqrt{ }$ & $\sqrt{ }$ & & $\sqrt{ }$ & $\sqrt{ }$ & $\sqrt{ }$ & $\sqrt{ }$ & & $\begin{array}{l}\text { Youssef et al. } \\
\text { [161] }\end{array}$ \\
\hline EPIC & $\begin{array}{l}\text { EPIC is a field-scale agroecosystem } \\
\text { model that simulates crop production. }\end{array}$ & $\sqrt{ }$ & & $\sqrt{ }$ & $\sqrt{ }$ & $\sqrt{ }$ & $\sqrt{ }$ & $\sqrt{ }$ & $\sqrt{ }$ & $\sqrt{ }$ & & $\begin{array}{c}\text { Gassman et al. } \\
\text { [162] }\end{array}$ \\
\hline FASSET & $\begin{array}{c}\text { FASSET is used to simulate crop growth } \\
\text { and yield, as well as daily soil N and C } \\
\text { fluxes in the } \\
\text { plant-soil-atmosphere continuum. }\end{array}$ & $\sqrt{ }$ & & $\sqrt{ }$ & $\sqrt{ }$ & & $\sqrt{ }$ & & $\sqrt{ }$ & $\sqrt{ }$ & & $\begin{array}{l}\text { Chatskikh } \\
\text { et al. [163] }\end{array}$ \\
\hline SPACSYS & $\begin{array}{l}\text { SPACSYS is a field-scale model and is } \\
\text { used to simulate daily } N \text { and } C \text { emissions } \\
\text { from arable land and grassland. }\end{array}$ & $\sqrt{ }$ & $\sqrt{ }$ & $\sqrt{ }$ & $\sqrt{ }$ & $\sqrt{ }$ & $\sqrt{ }$ & $\sqrt{ }$ & & $\sqrt{ }$ & $\sqrt{ }$ & Wu et al. [33] \\
\hline SWAT & $\begin{array}{l}\text { SWAT is a field or catchment scale, } \\
\text { process based model and is run at the } \\
\text { daily time step for simulating the } \\
\text { impacts of agricultural management } \\
\text { practices on hydrology and water quality. }\end{array}$ & $\sqrt{ }$ & $\sqrt{ }$ & $\sqrt{ }$ & $\sqrt{ }$ & & $\sqrt{ }$ & $\sqrt{ }$ & $\sqrt{ }$ & $\sqrt{ }$ & & $\begin{array}{l}\text { Arnold et al. } \\
\text { [32] }\end{array}$ \\
\hline TRIPLEX_GHG & $\begin{array}{l}\text { TRIPLEX-GHG is developed to simulate } \\
\mathrm{N}_{2} \mathrm{O} \text { emissions from global forests } \\
\text { and grassland. }\end{array}$ & $\sqrt{ }$ & $\sqrt{ }$ & $\sqrt{ }$ & $\sqrt{ }$ & $\sqrt{ }$ & $\sqrt{ }$ & $\sqrt{ }$ & & $\sqrt{ }$ & $\sqrt{ }$ & $\begin{array}{l}\text { Zhang et al. } \\
\text { [164] }\end{array}$ \\
\hline
\end{tabular}

where $\mathrm{N}$ is the $\mathrm{N}$ concentration and $\mathrm{T}$ is the soil temperature. $\sqrt{ }$ indicates the impact factor is considered.

Empirical models are not considered in this review because they can be challenging to apply outside of known conditions and thus have limited utility to test management practices or to predict the effects of future processes, such as climate change $[154,156,165]$. Therefore, the uncertainty of applying empirical models to conditions other than those used for their development is very high $[154,156]$.

Process-based modelling tools have the ability to simulate environmental conditions (e.g., soil moisture and temperature), crop growth and $\mathrm{N}$ fluxes under different management practices at the daily time step and at different scales (e.g., field, landscape or catchment) and once the required parameters are satisfactorily calibrated and validated they are helpful in identifying emission hot-spots and hot-moments, and are also useful in assessing the effectiveness of different management options for evaluating the impacts of 
climate and land use changes [141,168-171]. Compared to other process-based models in Table 4, the biogeochemical models (e.g., DAYCENT and DNDC) and the eco-hydrological model SWAT are among the most widely used models to simulate $\mathrm{N}_{2} \mathrm{O}$ emissions from agricultural systems and are well documented [30-32,172]. The SWAT model also includes the EPIC submodule, which simulates crop growth and $\mathrm{N}$ transport from the field $[32,173]$. Table 5 summarizes these three models in simulating $\mathrm{N}_{2} \mathrm{O}$ emissions from managed soils, specifically in terms of the input data required for the model, the model components, processes and the impact factors that are considered in each model $[25,30,168,173]$. For the SWAT model, we also include the current SWAT $\mathrm{N}_{2} \mathrm{O}$ submodules, which are reviewed in Ghimire et al. [28].

Table 5. Summary of three process-based models in simulating $\mathrm{N}_{2} \mathrm{O}$ emissions.

\begin{tabular}{|c|c|c|c|}
\hline Model & Input Data & $\begin{array}{l}\text { Physical Processes and } \\
\text { Products Partitioning }\end{array}$ & Considered Environmental Factors \\
\hline \multirow{4}{*}{ DAYCENT } & \multirow{4}{*}{$\begin{array}{l}\text { Daily weather variables, site-specific } \\
\text { soil properties, and land use. }\end{array}$} & Nitrification & Soil N, temperature, WFPS and $\mathrm{pH}$ \\
\hline & & Denitrification & Soil N, SOC and WFPS \\
\hline & & $\mathrm{N}_{2} / \mathrm{N}_{2} \mathrm{O}$ & Soil N, SOC and WFPS \\
\hline & & $\mathrm{NO}_{x} / \mathrm{N}_{2} \mathrm{O}$ & Soil WFPS \\
\hline \multirow{3}{*}{ DNDC } & \multirow{3}{*}{$\begin{array}{l}\text { Daily weather variables, soil properties, } \\
\text { and management practices. }\end{array}$} & Nitrification & $\begin{array}{c}\text { Nitrifiers, soil N, WFPS, temperature, } \\
\text { and } \mathrm{pH}\end{array}$ \\
\hline & & Denitrification & $\begin{array}{l}\text { De-nitrifiers, } \mathrm{SOC} \text {, soil } \mathrm{N}, \\
\text { temperature, and } \mathrm{pH}\end{array}$ \\
\hline & & $\mathrm{NO}_{\mathrm{x}}, \mathrm{N}_{2}$ & Soil pH \\
\hline \multirow[b]{2}{*}{ SWAT } & \multirow{2}{*}{$\begin{array}{l}\text { DEM, soil properties, daily weather } \\
\text { variables, and management practices. }\end{array}$} & Nitrification & Soil N, WFPS, temperature and $\mathrm{pH}$ \\
\hline & & Denitrification & $\begin{array}{c}\text { Soil N, SOC, moisture, temperature } \\
\text { and } \mathrm{pH}\end{array}$ \\
\hline
\end{tabular}

We programmed the main equations responsible for $\mathrm{N}_{2} \mathrm{O}$ emissions in the models DAYCENT, DNDC and SWAT using " $R$ " programming language to plot and visualize the differences of the representation of each environmental factor on $\mathrm{N}_{2} \mathrm{O}$. The results for each model are discussed below and presented in Figures 4-6. The link to related $\mathrm{R}$ codes refers to Supplementary materials.

\subsection{Nitrification Processes}

The DAYCENT model calculates nitrification as a function of soil $\mathrm{NH}_{4}{ }^{+}$level, soil temperature, soil $\mathrm{pH}$, soil moisture and a $\mathrm{N}$ turnover coefficient (Equations (S1)-(S7)) [25]. The $\mathrm{N}$ turnover coefficient is a function of the soil texture, soil $\mathrm{N}$ fertility, $\mathrm{N}$ fertilizer additions, and soil management practices. In DAYCENT, the nitrification rate increases exponentially with increasing $\mathrm{NH}_{4}{ }^{+}$levels and soil temperature (Figure 4A,B). In DAYCENT, the relationship between the nitrification rate and soil $\mathrm{pH}$ is the inverse of tangent function (Figure 4C). The effect of WFPS on nitrification is a function of the soil texture, whereby a maximum nitrification rate is reached for sandy soils at WFPS 0.55 and for medium texture soils at WFPS 0.61 (Figure 4D). In DAYCENT, the $\mathrm{N}$ turnover coefficient is treated as a site specific parameter that needs to be estimated using observed $\mathrm{N}_{2} \mathrm{O}$ data or observed potential soil $\mathrm{N}$ mineralized data. 
A $\mathrm{NH} 4$ (Daycent)

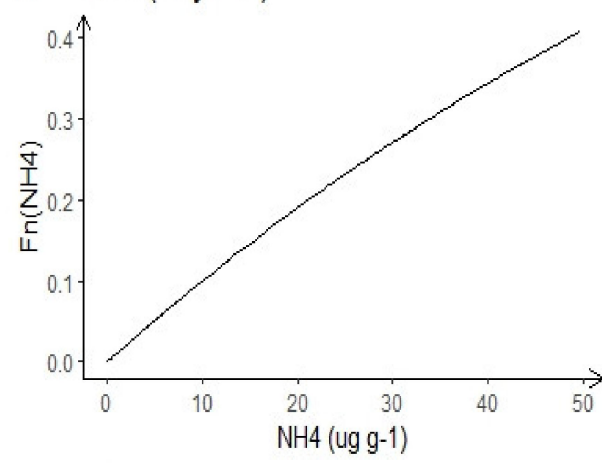

C Soil pH

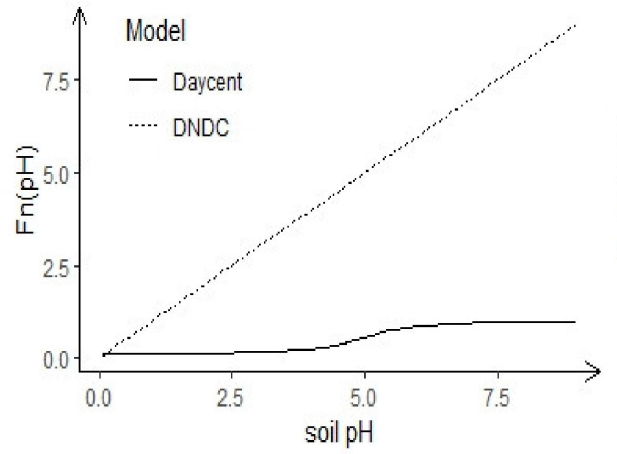

B Soil Temperature

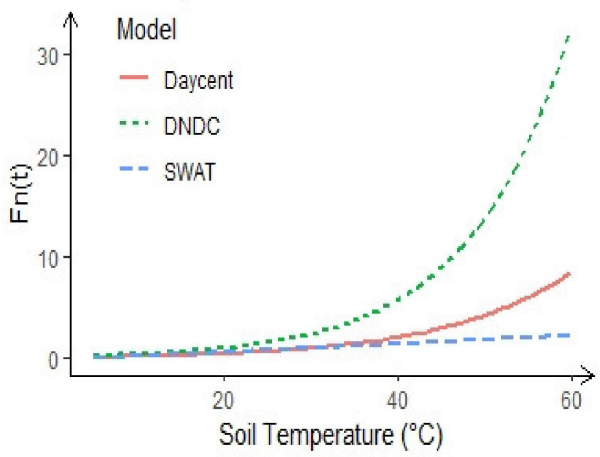

D WFPS

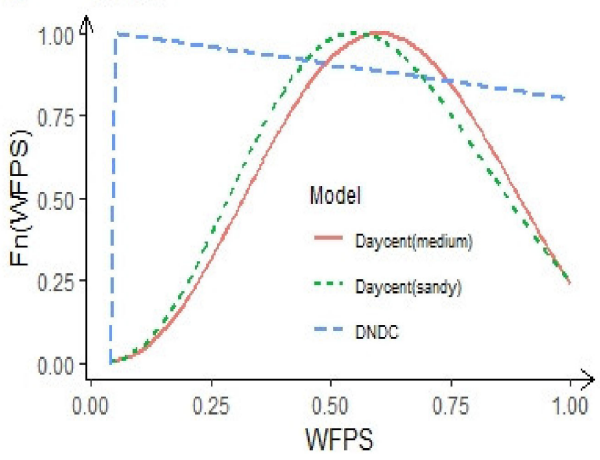

Figure 4. The impact of soil $\mathrm{NH}_{4}{ }^{+}(\mathbf{A})$, soil temperature (B), soil pH (C) and WFPS (D) on nitrification processes in DAYCENT, DNDC and SWAT.
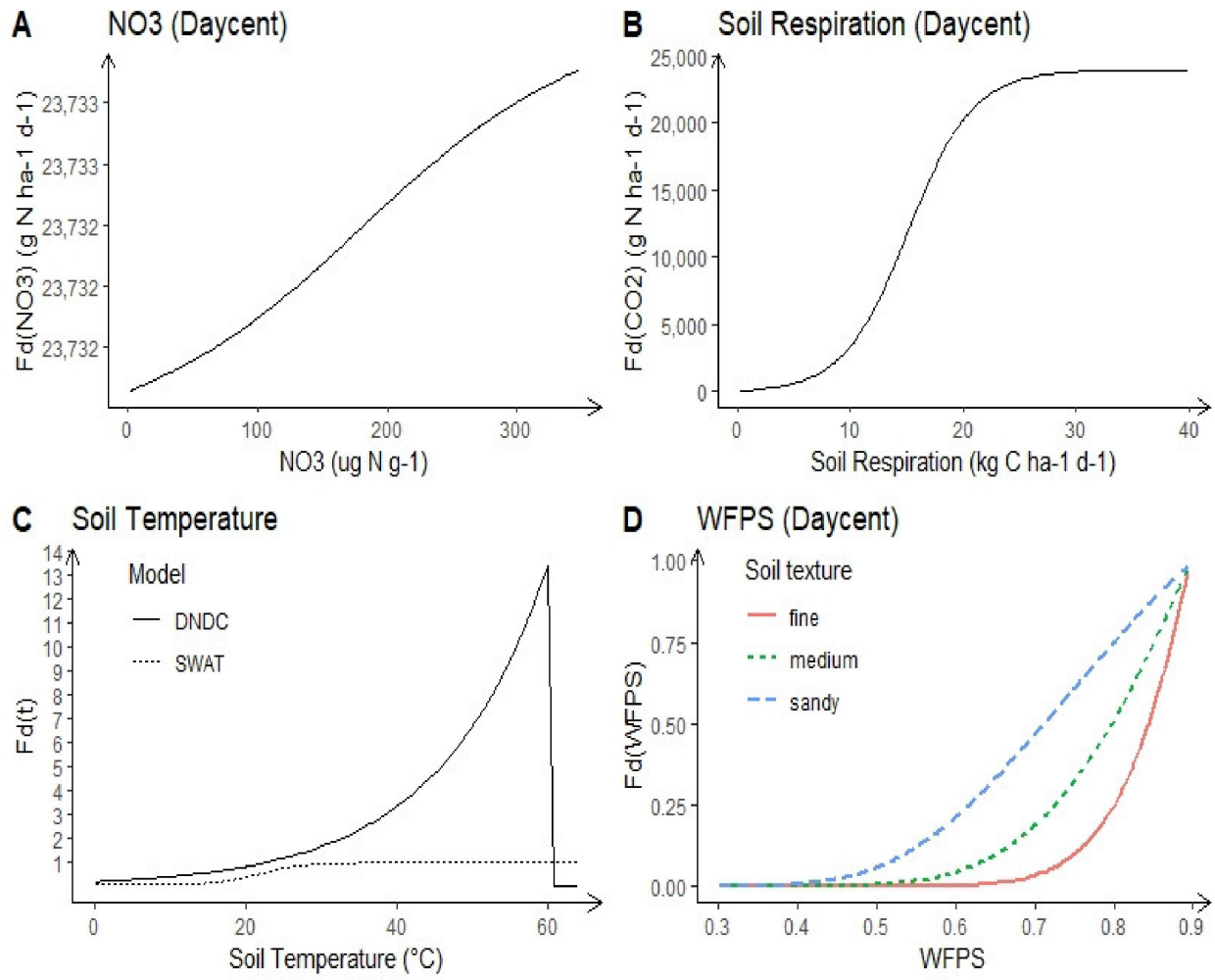

Figure 5. The impact of soil $\mathrm{NO}_{3}{ }^{-}$(A), soil respiration (B), soil temperature (C), and WFPS (D) on denitrification processes in DAYCENT, DNDC and SWAT. 
A NO3 (Daycent)
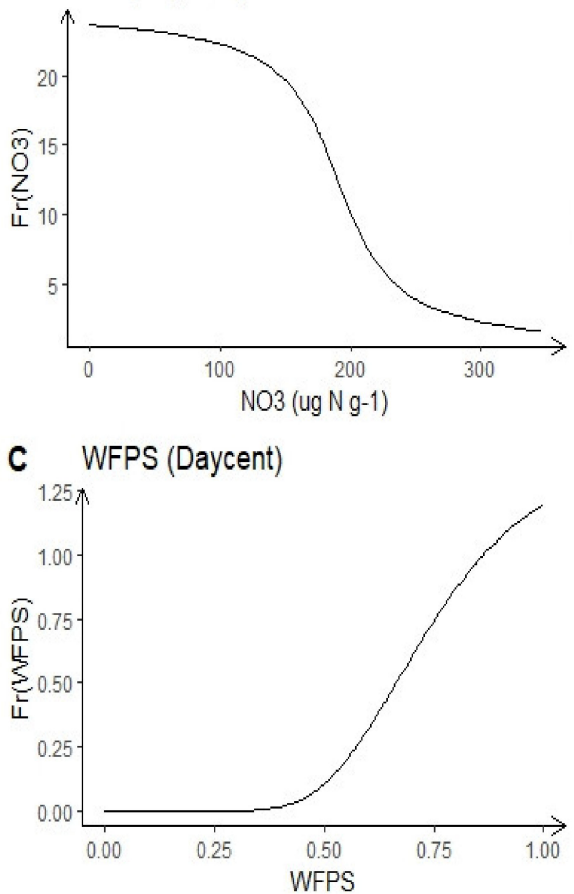

B Soil Respiration (Daycent)

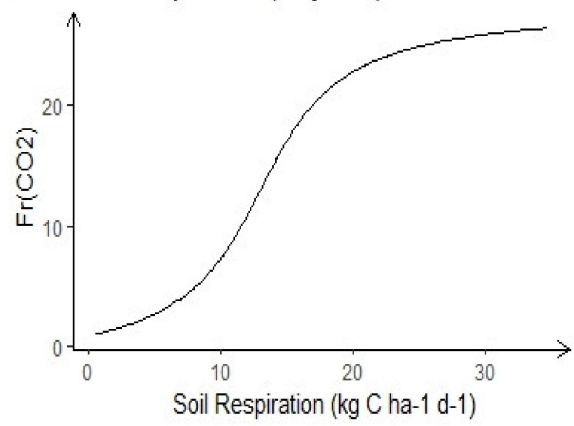

D Soil pH (DNDC)

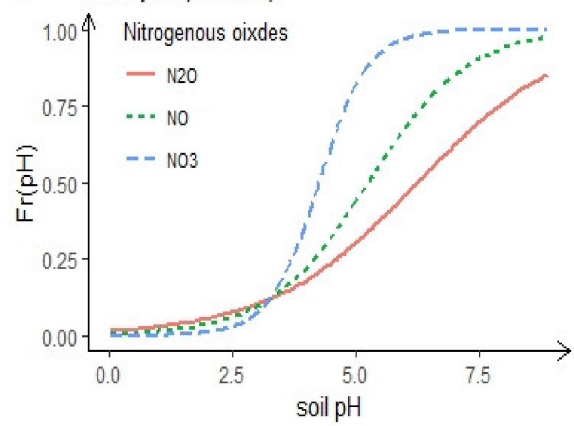

Figure 6. The impact of soil $\mathrm{NO}_{3}{ }^{-}$(A), soil respiration (B), WFPS (C), and soil $\mathrm{pH}$ (D) on the $\mathrm{N}_{2} / \mathrm{N}_{2} \mathrm{O}$ ratio in DAYCENT and DNDC. The DNDC model shows the impact of soil $\mathrm{pH}$ on each nitrogenous oxide (D).

The rate of nitrification in the DNDC model is regulated by soil temperature, soil moisture, soil $\mathrm{pH}$ and nitrifier activity, which relies on two substrates: the dissolved organic $\mathrm{C}$ and $\mathrm{NH}_{4}{ }^{+}$concentration (Equations (S20)-(S27)) [136]. The nitrification rate linearly increases as the concentration of $\mathrm{NH}_{4}{ }^{+}$increases in the soil [172]. Similar to DAYCENT, the nitrification rate in the DNDC model also increases exponentially with soil temperature. However, the magnitude is much higher (Figure 4B). The effect of soil $\mathrm{pH}$ on nitrification is linear with a slope of 1 (Figure 4C). In the DNDC model, when WFPS $<0.05$, the impact on nitrification is zero. When the WFPS $>0.05$, the effect on nitrification has a negative linear association (Figure 4D).

The SWAT model considers nitrification to be a function of soil $\mathrm{NH}_{4}{ }^{+}$, soil moisture and soil temperature (Equations (S44)-(S49)) [173]. The SWAT model uses the amount of $\mathrm{NH}_{4}{ }^{+}$in each soil layer, the nitrification regulator and volatilization regulator to calculate the total amount of nitrification and ammonia volatilization, and then partitions $\mathrm{N}$ between the two processes. The nitrification regulator is a function of soil temperature and soil water content. The volatilization regulator is a function of soil temperature, volatilization depth and cation exchange. In SWAT, nitrification occurs only when the soil temperature exceeds $5{ }^{\circ} \mathrm{C}$ and the correlation is linear, which is different to DAYCENT and DNDC (Figure 4B). The SWAT model calculates the impact of soil water on nitrification not by using the WFPS, but rather by using the soil water content of each soil layer, the wilting point water content, and the field capacity water content (Equations (S46) and (S47)), which vary with soil texture, climate and crop type [137]. SWAT does not take into account the changes of soil $\mathrm{pH}$ and therefore does not consider the impact of soil $\mathrm{pH}$ on nitrification.

\subsection{Denitrification Processes}

The DAYCENT model calculates denitrification to be a function of soil $\mathrm{NO}_{3}{ }^{-}$, soil respiration and the WFPS (Equations (S8)-(S11)). The impact of soil $\mathrm{NO}_{3}{ }^{-}$on denitrification is the inverse of a tangent function (Figure 5A), and the effect of soil respiration on denitrification is an exponential function (Figure 5B). Soil respiration is assumed to be cor- 
related to the $C$ substrate. The denitrification rate increases exponentially with increasing values of WFPS, and particularly when WFPS $>0.6$, in all soil textures. In finer textured soil, the denitrification rate is slower at lower WFPS and only increases significantly after WFPS $>0.7$ (Figure 5D). The representation of the impact of soil moisture on simulated $\mathrm{N}_{2} \mathrm{O}$ emissions fits well with the literature described in chapter 2. The DAYCENT model does not consider the impacts of soil temperature and soil $\mathrm{pH}$ on denitrification.

In the DNDC model, the denitrification process is a series of microbe-mediated reactions that sequentially reduce $\mathrm{NO}_{3}{ }^{-}$to $\mathrm{NO}_{2}{ }^{-}, \mathrm{NO}, \mathrm{N}_{2} \mathrm{O}$, and finally to $\mathrm{N}_{2}$. The rate of each reduction step is a function of denitrifiers, DOC, corresponding nitrogenous oxides, temperature, Eh and $\mathrm{pH}$ in soils (Equations (S28)-(S43)) [172]. The DOC and the concentration of nitrogenous oxides control the growth of denitrifiers. The relationship between soil temperature and the reduction rate is exponential when soil temperature is $<60^{\circ} \mathrm{C}$. When soil temperature is $>60^{\circ} \mathrm{C}$, the impact on denitrification is zero (Figure $5 \mathrm{C}$ ). Denitrifying soil conditions are assumed if the environmental Eh drops to $500 \mathrm{mV}$ or lower due to the oxygen depletion in the soil [172]. In DNDC the denitrification rate increases exponentially with increasing soil $\mathrm{pH}$, and the slopes are different depending on nitrogenous oxides (Figure 6D). The impact of soil $\mathrm{pH}$ on simulated $\mathrm{N}_{2} \mathrm{O}$ mimics the findings of Rochester et al. [74].

The SWAT model treats denitrification as a function of soil $\mathrm{NO}_{3}{ }^{-}$, soil organic $\mathrm{C}$, soil temperature, and soil moisture (Equations (S50)-(S53)) whereby the soil organic $\mathrm{C}$ amount is an input value. The denitrification rate increases exponentially with increasing soil temperature (Figure 5C), but the rate never falls below 0.1. The impact of soil moisture on denitrification is based on the ratio of soil water content and the water content at field capacity, which changes with soil texture, climate and crops. The impact of soil moisture on denitrification never falls below 0.05 .

\subsection{Partitioning $\mathrm{N}_{2} \mathrm{O}$ from $\mathrm{N}_{2}$}

DAYCENT firstly models the total denitrification rate $\left(\mathrm{N}_{2}+\mathrm{N}_{2} \mathrm{O}\right)$ and then partitions $\mathrm{N}_{2}$ from $\mathrm{N}_{2} \mathrm{O}$. It considers the $\mathrm{N}_{2} / \mathrm{N}_{2} \mathrm{O}$ ratio as a function of soil $\mathrm{NO}_{3}{ }^{-}$, soil respiration and WFPS (Equations (S12)-(S15)) (Figure 6A-C). The $\mathrm{N}_{2} / \mathrm{N}_{2} \mathrm{O}$ ratio decreases as soil $\mathrm{NO}_{3}{ }^{-}$increases (Figure $6 \mathrm{~A}$ ), and high soil $\mathrm{NO}_{3}{ }^{-}$inhibits the reduction of $\mathrm{N}_{2} \mathrm{O}$ to $\mathrm{N}_{2}$. The relationship of soil respiration to the $\mathrm{N}_{2} / \mathrm{N}_{2} \mathrm{O}$ ratio is the inverse of tangent function (Figure 6B) whereby the $\mathrm{N}_{2} / \mathrm{N}_{2} \mathrm{O}$ ratio increases with increasing soil respiration. When WFPS $>0.5$, the $\mathrm{N}_{2} / \mathrm{N}_{2} \mathrm{O}$ ratio also exponentially increases (Figure $6 \mathrm{C}$ ). The impact of soil $\mathrm{NO}_{3}{ }^{-}$, soil respiration and WFPS on simulated $\mathrm{N}_{2} \mathrm{O}$ emissions in the DAYCENT model is similar to the information presented in chapter 2 .

Similar to the denitrification process in DNDC, the DNDC model partitions nitrogenous oxides by sequentially reducing $\mathrm{NO}_{3}{ }^{-}$to $\mathrm{NO}_{2}{ }^{-}, \mathrm{NO}, \mathrm{N}_{2} \mathrm{O}$, and finally to $\mathrm{N}_{2}$.

The SWAT model does not partition $\mathrm{N}_{2} \mathrm{O}$ from nitrification and denitrification products (e.g., $\mathrm{NO}_{x}$ and $\mathrm{N}_{2}$ ). Some studies have been undertaken to specially develop an $\mathrm{N}_{2} \mathrm{O}$-submodule based on the SWAT model. Yang et al. [174] enhanced the SWAT model by directly integrating the DAYCENT model into the SWAT model. Shrestha et al. [170] developed a SWAT $\mathrm{N}_{2} \mathrm{O}$-submodule mainly by using equations from Parton et al. [25,30], which were used to develop DAYCENT, and added the equation for the impact of soil temperature on denitrification (Equation (S52)). Wagena et al. [175] developed a SWAT-GHG model by also using the equations from Parton et al. [25]; however, their study considered the impacts of soil $\mathrm{NH}_{4}{ }^{+}$and soil moisture on nitrification that are based on the SWAT model and not directly on Parton's equations (Equations (S44)-(S47) and (S49)). Wagena et al. [175] also developed equations for considering the impacts of soil temperature and soil $\mathrm{pH}$ on denitrification as well as the impacts of soil $\mathrm{pH}$ on the $\mathrm{N}_{2} / \mathrm{N}_{2} \mathrm{O}$ ratio (Equations (S52), (S54) and (S55)). They treat soil $\mathrm{pH}$ as one value for the region instead of differentiating based on soil type at the local HRU level.

Based on the above analysis, we can state that the representations of soil temperature on nitrification in DAYCENT and in DNDC are as an exponential function, while in SWAT 
it is linear. Furthermore, the calculated $\mathrm{N}_{2} \mathrm{O}$ values based on the temperature formulas in these three models vary greatly.

Equations in the models showing the relations between soil $\mathrm{NH}_{4}{ }^{+}$and nitrification in SWAT and DNDC are linear, while in DAYCENT this is exponential. The impacts of soil $\mathrm{pH}$ on nitrification are greater in DNDC than DAYCENT while in SWAT they are neglected. The impact of WFPS on nitrification in DNDC is negative linear whereby the maximum nitrification occurs when WFPS $=0.05$, then decreases as WFPS increases. This is not in accordance with the peer-reviewed literature. However, Li et al. [31] showed DNDC simulated nitrification reasonably, whereas DAYCENT overestimated the nitrification.

Other model differences are mainly related to the partitioning of $\mathrm{N}_{2} \mathrm{O}$. The SWAT $\mathrm{N}_{2} \mathrm{O}$ submodule and the DAYCENT model firstly calculate total denitrification $\left(\mathrm{N}_{2} \mathrm{O}+\mathrm{N}_{2}\right)$ and then partition $\mathrm{N}_{2} \mathrm{O}$ from $\mathrm{N}_{2}$. The DAYCENT model even partitions $\mathrm{N}_{2} \mathrm{O}$ from $\mathrm{NO}_{\mathrm{x}}$. The impacts of environmental factors on denitrification and the $\mathrm{N}_{2} / \mathrm{N}_{2} \mathrm{O}$ ratio are considered separately. The DNDC model simulates each stage of denitrification explicitly and the $\mathrm{NO}_{\mathrm{x}}, \mathrm{N}_{2} \mathrm{O}$ and $\mathrm{N}_{2}$ amounts, which are calculated directly. The impacts of soil $\mathrm{N}$, SOC and soil $\mathrm{pH}$ on each stage depend on different functions of nitrogenous oxides, SOC and soil pH. David et al. [176] compared simulated denitrification for a corn and soybean agroecosystem from DAYCENT, SWAT and DNDC. The DAYCENT and DNDC models, which are biogeochemistry-constructed models, are more similar to each other, and overall simulate lower denitrification fluxes compared to the agronomist-developed and croporiented SWAT model [176]. DAYCENT predicted an even split of $50 \%$ of denitrification for $\mathrm{N}_{2} \mathrm{O}$ and $\mathrm{N}_{2}$, whereas the simulated $\mathrm{N}_{2} \mathrm{O}$ from DNDC depends on the model version and its simulated denitrification ( $22-75 \%$ denitrification).

The biogeochemical DAYCENT model considers partitioning $\mathrm{N}_{2} \mathrm{O}$ from both $\mathrm{N}_{2}$ and $\mathrm{NO}_{\mathrm{x}}$. In DAYCENT, the semi-empirical equations for describing the impacts of environmental factors on $\mathrm{N}_{2} \mathrm{O}$ emissions are developed based on experimental data, and are also used to develop $\mathrm{N}_{2} \mathrm{O}$ submodules for other models $[169,174,175]$. Especially, the impacts of WFPS on nitrification and denitrification are considered for different soil texture. However, the DAYCENT model does not include the impacts of soil temperature and soil $\mathrm{pH}$ on denitrification and the ratio of $\mathrm{N}_{2} / \mathrm{N}_{2} \mathrm{O}$. In addition, the consideration of land management strategies is not possible in the DAYCENT model, for example, fertilizer type and placement are not represented, although the current DAYCENT model can simulate limited management events (e.g., the amounts of $\mathrm{N}$ input) [177].

The DNDC model is also a kinetic model, which requires some parameters that are not commonly measured in the field, for example, it is difficult to measure and/or validate soil microbial biomass [178]. Even though some researchers use crop yield to validate model simulations, the uncertainty of the simulated $\mathrm{N}_{2} \mathrm{O}$ emissions using the DNDC model still needs to be more widely quantified $[179,180]$.

The SWAT model is an eco-hydrological model, which can be used to simulate hydrological processes, crop growth and nutrient fluxes at the catchment scale. However, SWAT does not partition $\mathrm{N}_{2} \mathrm{O}$ from other products (e.g., $\mathrm{NO}_{x}$ and $\mathrm{N}_{2}$ ). Even though a few studies developed SWAT $\mathrm{N}_{2} \mathrm{O}$ submodules, the partitioning of $\mathrm{N}_{2} \mathrm{O}$ from $\mathrm{NO}_{x}$ is still missing in all of the current developed SWAT submodules $[32,169,175]$. In addition, the widely used SWAT model does not simulate the dynamics of changing soil $\mathrm{pH}$, thus the impact of soil $\mathrm{pH}$ on nitrification and denitrification is not considered. The SWAT submodules developed specifically for $\mathrm{N}_{2} \mathrm{O}$ emissions also treat soil $\mathrm{pH}$ only as one value instead of differentiating at the HRU level [175].

The DAYCENT, DNDC models and the SWAT $\mathrm{N}_{2} \mathrm{O}$-submodule can be used to simulate long-term $\mathrm{N}_{2} \mathrm{O}$ emissions from agricultural soils at the daily time step and at different scales. Compared to the measured $\mathrm{N}_{2} \mathrm{O}$ data, the models' performances are highly variable and there is little agreement in the literature. Zimmermann et al. [80] reported that DAYCENT and DNDC overestimated cumulative $\mathrm{N}_{2} \mathrm{O}$ fluxes, while Gaillard et al. [180] reported underestimation of $\mathrm{N}_{2} \mathrm{O}$ fluxes for both models. Fitton et al. [181] showed that DAYCENT could provide a good estimation of annual $\mathrm{N}_{2} \mathrm{O}$ emissions. The different versions of 
SWAT $\mathrm{N}_{2} \mathrm{O}$-submodules also report a wide range of performances for simulating $\mathrm{N}_{2} \mathrm{O}$ emissions $[169,175]$.

In addition to the simulated comparisons with measured $\mathrm{N}_{2} \mathrm{O}$ data, other environmental processes can be compared to measured data. For example, DAYCENT and DNDC can simulate crop yields well when compared to observed crop yields [118,179,181,182]. Current literature on the SWAT $\mathrm{N}_{2} \mathrm{O}$ submodule did not report on SWAT performance for simulating crop yields. However, the SWAT model is based on the EPIC submodule and indeed has the ability to simulate crop growth and crop yields [32,173].

Soil moisture is another variable that can be compared in the models. DAYCENT and DNDC had relatively poor performances for simulating soil water [80], whereas SWAT could simulate soil moisture quite well, which reflects the robust hydrological processes in the SWAT model [169].

The models' performances for simulating nitrification, denitrification and $\mathrm{N}_{2} \mathrm{O}$ emissions indicates that processes and parameters governing management practices, crop growth, and water fluxes in each model show large differences and strongly influence the simulations of soil microbes, soil N, SOC, soil temperature, soil $\mathrm{pH}$ and soil water availability $[183,184]$. These environmental factors further affect the rates of nitrification, denitrification and $\mathrm{N}_{2} \mathrm{O}$ emissions as discussed in chapter 2. Different types of field observations (e.g., soil moisture, soil temperature, soil $\mathrm{NO}_{3}{ }^{-}$and crop yields) should be compared with simulated values to improve model performance for simulating the $\mathrm{N}$-cycle and $\mathrm{N}_{2} \mathrm{O}$ emissions [180,182]. In addition, the measurement of $\mathrm{N}_{2} \mathrm{O}$ emissions (e.g., length of measurements, applied method for $\mathrm{N}_{2} \mathrm{O}$ measurement and the scales) also influence the evaluation of model performance $[119,185]$.

\section{Summary \& Conclusions}

In this review, we group factors that influence $\mathrm{N}_{2} \mathrm{O}$ emissions into environmental factors, management factors and measurement factors. Environmental factors control the rate of nitrification and denitrification. Management factors control how much $\mathrm{N}$ is input into soils, and influence the environmental factors. Measurement factors contribute to our process of understanding $\mathrm{N}_{2} \mathrm{O}$ emissions, and while they do not influence $\mathrm{N}_{2} \mathrm{O}$ emissions directly, they affect the accuracy (and uncertainty) of measured $\mathrm{N}_{2} \mathrm{O}$ data, which in turn is important for model development and validation. We described how these factors influence nitrification and denitrification processes and the products of the $\mathrm{N}_{2} / \mathrm{N}_{2} \mathrm{O}$ ratio.

Overall, there is general agreement in the literature about the main factors that influence $\mathrm{N}_{2} \mathrm{O}$ emissions; however, the factors and the significance of their impacts on nitrification, denitrification and the $\mathrm{N}_{2} / \mathrm{N}_{2} \mathrm{O}$ ratio vary with soil and climate types. The impacts of environmental factors on $\mathrm{N}_{2} \mathrm{O}$ emissions and the proportion of $\mathrm{N}_{2} \mathrm{O}$ emissions from nitrified $\mathrm{N}$ also vary with soil and climate type, and are not sufficiently researched. The effect of soil $\mathrm{pH}$ and how it affects denitrification is another area which is not resolved.

We compared and analyzed the algorithms responsible for $\mathrm{N}_{2} \mathrm{O}$ simulations in DAYCENT, DNDC, and SWAT for each of the impact factors. The representation of most of the impact factors in these three models are in accordance with the literature that we reviewed, although some simulated $\mathrm{N}_{2} \mathrm{O}$ results are clearly different from the literature. Current models for simulating $\mathrm{N}_{2} \mathrm{O}$ emissions use empirical equations or values, which were developed/regressed for specific soil and climate types. For example, the proportion of $\mathrm{N}_{2} \mathrm{O}$ emissions from nitrification processes are set to a single value in the DNDC model and in the recently developed SWAT $\mathrm{N}_{2} \mathrm{O}$ submodules.

The three widely used process-based models (DAYCENT, DNDC, and SWAT) have advantages and weaknesses for simulating $\mathrm{N}_{2} \mathrm{O}$ emissions from managed soils. DAYCENT and DNDC are biogeochemical models and can be used to simulate small-scale $\mathrm{N}$ dynamics in soils. SWAT is an eco-hydrological model and can be used to simulate $\mathrm{N}$ fluxes from crop production and at the catchment scale because reactive nitrogen is highly mobile and is easily transported by water. The main disadvantages of the models include the following: a particular weakness of DAYCENT is the inability to represent land management strategies, 
because $\mathrm{N}_{2} \mathrm{O}$ is mainly emitted from agriculturally managed soils. Some parameters (e.g., soil microbial biomass) included in the DNDC model are difficult to validate. The SWAT model cannot completely partition $\mathrm{N}_{2} \mathrm{O}$ from $\mathrm{NO}_{x}$ and $\mathrm{N}_{2}$, and does not capture the dynamic changes in soil $\mathrm{pH}$.

It is difficult to conclude which simulation model is better for representing $\mathrm{N}_{2} \mathrm{O}$ fluxes, or which model consistently overestimates or underestimates $\mathrm{N}_{2} \mathrm{O}$ emissions because of the interactions of several simulated impact factors on simulated $\mathrm{N}$ components in the model. Most model-based studies focus on regions where field measured data are available for model calibration and validation. We recommend a more holistic approach to model calibration/validation whereby several simulated variables related to $\mathrm{N}_{2} \mathrm{O}$ emissions in the model, such as soil $\mathrm{NO}_{3}{ }^{-}$, soil water, or crop yields should be compared with measured data when possible, as this would improve the simulation of $\mathrm{N}_{2} \mathrm{O}$ in the soil system.

Supplementary Materials: The following are available online at https:/ / www.mdpi.com/article/10 .3390 /agronomy11040770/s1. Table S1. Factors that influence N2O emissions from peer-reviewed literature. Table S2. Soil texture parameters for nitrification rate. Table S3. Soil texture parameters for denitrification rate.

Author Contributions: Conceptualization, C.W. and B.M.; writing-original draft preparation, C.W. and B.M.; writing-review and editing, B.A., K.S., and B.M.; supervision, B.M., K.S. and B.A. All authors have read and agreed to the published version of the manuscript.

Funding: This work is supported by the China Scholarship Council [grant number 201708620181]. Open access funding is provided by the University of Natural Resources and Life sciences, Vienna (BOKU) and Human river systems in the 21st century (HR21) (BOKU).

Institutional Review Board Statement: Not applicable.

Informed Consent Statement: Not applicable.

Data Availability Statement: No new data were created or analyzed in this study. Data sharing is not applicable to this article.

Conflicts of Interest: The authors declare no conflict of interest.

\section{References}

1. Fowler, D.; Steadman, C.E.; Stevenson, D.; Coyle, M.; Rees, R.M.; Skiba, U.M.; Sutton, M.A.; Cape, J.N.; Dore, A.J.; Vieno, M.; et al. Effects of global change during the 21st century on the nitrogen cycle. Atmos. Chem. Phys. 2015, 15, 13849-13893. [CrossRef]

2. Beaulieu, J.J.; Tank, J.L.; Hamilton, S.K.; Wollheim, W.M.; Hall, R.O.; Mulholland, P.J.; Peterson, B.J.; Ashkenas, L.R.; Cooper, L.W.; Dahm, C.N.; et al. Nitrous oxide emission from denitrification in stream and river networks. Proc. Natl. Acad. Sci. USA 2010, 108, 214-219. [CrossRef] [PubMed]

3. Flückiger, J.; Dällenbach, A.; Blunier, T.; Stauffer, B.; Stocker, T.F.; Raynaud, D.; Barnola, J.-M. Variations in Atmospheric $\mathrm{N}_{2} \mathrm{O}$ Concentration during Abrupt Climatic Changes. Science 1999, 285, 227-230. [CrossRef]

4. Seitzinger, S.P.; Phillips, L. Nitrogen stewardship in the Anthropocene. Science 2017, 357, 350-351. [CrossRef] [PubMed]

5. Smith, P.; Clark, H.; Dong, H.; Elsiddig, E.A.; Haberl, H.; Harper, R.; House, J.; Jafari, M.; Masera, O.; Mbow, C.; et al. Agriculture, Forestry and Other Land Use (AFOLU). In Climate Change 2014: Mitigation of Climate Change. Contribution of Working Group III to the Fifth Assessment Report of the Intergovernmental Panel on Climate Change; Edenhofer, O.R., Pichs-Madruga, Y., Sokona, E., Farahani, S., Kadner, K., Seyboth, A., Adler, I., Baum, S., Brunner, P., Eickemeier, B., et al., Eds.; Cambridge University Press: Cambridge, UK; New York, NY, USA; Available online: https://www.ipcc.ch/pdf/assessment-report/ar5/wg3/ipcc_wg3_ar5_chapter11.pdf (accessed on 20 August 2018).

6. Kravchenko, A.N.; Toosi, E.R.; Guber, A.K.; Ostrom, N.E.; Yu, J.; Azeem, K.; Rivers, M.L.; Robertson, G.P. Hotspots of soil N2 O emission enhanced through water absorption by plant residue. Nat. Geosci. 2017, 10, 496-500. [CrossRef]

7. Mosier, A.R. Nitrous oxide emissions from agricultural soils. Fertil. Res. 1994, 37, 191-200. [CrossRef]

8. Myhre, G.D.; Shindell, F.-M.; Bréon, W.; Collins, J.; Fuglestvedt, J.; Huang, D.; Koch, J.-F.; Lamarque, D.; Lee, B.; Mendoza, T.; et al. Anthropogenic and Natural Radiative Forcing. In Climate Change 2013: The Physical Science Basis. Contribution of Working Group I to the Fifth Assessment Report of the Intergovernmental Panel on Climate Change; Stocker, T.F., Qin, D., Plattner, G.-K., Tignor, M., Allen, S.K., Boschung, J., Nauels, A., Xia, Y., Bex, V., Midgley, P.M., Eds.; Cambridge University Press: Cambridge, UK; New York, NY, USA; Available online: https://www.ipcc.ch/site/assets/uploads/2018/02/WG1AR5_Chapter08_FINAL.pdf (accessed on 20 August 2018). 
9. Tubiello, F.N.; Salvatore, M.; Cóndor Golec, R.D.; Ferrara, A.; Rossi, S.; Biancalani, R.; Federici, S.; Jacobs, H.; Flammini, A. Agriculture, Forestry and Other Land Use Emissions by Sources and Removals by Sinks, ESS Working Paper No.2; FAO: Rome, Italy, 2014. [CrossRef]

10. Petrescu, A.M.R.; Peters, G.P.; Janssens-Maenhout, G.; Ciais, P.; Tubiello, F.N.; Grassi, G.; Nabuurs, G.-J.; Leip, A.; Carmona-Garcia, G.; Winiwarter, W.; et al. European anthropogenic AFOLU emissions and their uncertainties: A review and benchmark data. Earth Syst. Sci. Data 2019, 12, 961-1001. [CrossRef]

11. Ciais, P.C.; Sabine, G.; Bala, L.; Bopp, V.; Brovkin, J.; Canadell, A.; Chhabra, R.; DeFries, J.; Galloway, M.; Heimann, C.; et al. Carbon and Other Biogeochemical Cycles. In In Climate Change 2013: The Physical Science Basis. Contribution of Working Group I to the Fifth Assessment Report of the Intergovernmental Panel on Climate Change; Stocker, T.F., Qin, D., Plattner, G.-K., Tignor, M., Allen, S.K., Boschung, J., Nauels, A., Xia, Y., Bex, V., Midgley, P.M., Eds.; Cambridge University Press: Cambridge, UK; New York, NY, USA; Available online: https:/ / www.ipcc.ch/site/assets/uploads/2018/02/WG1AR5_Chapter06_FINAL.pdf (accessed on 21 August 2018).

12. De Klein, C.A.M.; Sherlock, R.R.; Cameron, K.C.; Van Der Weerden, T.J. Nitrous oxide emissions from agricultural soils in New Zealand-A review of current knowledge and directions for future research. J. R. Soc. N. Z. 2001, 31, 543-574. [CrossRef]

13. Hergoualc'h, K.; Akiyama, H.; Bernoux, M.; Chirinda, N.; del Prado, A.; Kasimir, Å.; MacDonald, J.D.; Ogle, S.M.; Regina, K.; van der Weerden, T.J. IPCC: $\mathrm{N}_{2} \mathrm{O}$ Emissions from Managed Soils, and $\mathrm{CO}_{2}$ Emissions from Lime and Urea Application, Chap.11, In 2019 Refinement to the 2006 IPCC Guidelines for National Greenhouse Gas Inventories. Available online: https: / www.ipcc-nggip.iges.or. jp/public/2019rf/pdf/4_Volume4/19R_V4_Ch11_Soils_N2O_CO2.pdf (accessed on 23 September 2019).

14. Winiwarter, W.; Klimont, Z The role of $\mathrm{N}$-gases $\left(\mathrm{N}_{2} \mathrm{O}, \mathrm{NO}_{\mathrm{x}}, \mathrm{NH}_{3}\right)$ in cost-effective strategies to reduce greenhouse gas emissions and air pollution in Europe. Curr. Opin. Environ. Sustain. 2011, 3, 438-445. [CrossRef]

15. De Klein, C.; Novoa, R.S.A.; Ogle, S.; Smith, K.A.; Rochette, P.; Wirth, C.T.; McConkey, B.G.; Mosier, A.; Williams, S.A. In 2006 IPCC Guidelines for National Greenhouse Gas Inventories. Volume 4: Agriculture, Forestry and Other Land Use. Chapter 11: $\mathrm{N}_{2} \mathrm{O}$ Emissions from Managed Soils, and $\mathrm{CO}_{2}$ Emissions from Lime and Urea Application. Intergovernmental Panel on Climate Change (IPCC), Technical Report 4-88788-032-4, Geneva, Switzerland. Available online: https:/ /www.ipcc-nggip.iges.or.jp/ public/2006gl/pdf/4_Volume4/V4_11_Ch11_N2O\&CO2.pdf (accessed on 19 August 2018).

16. Abdalla, M.; Smith, P.; Williams, M. Emissions of nitrous oxide from agriculture: Responses to management and climate change. In Understanding Greenhouse Gas Emissions from Agricultural Management; American Chemical Society (ACS): Washington, DC, USA, 2011; pp. 343-370.

17. Signor, D.; Cerri, C.E.P. Nitrous oxide emissions in agricultural soils: A review. Pesqui. Agropecuária Trop. 2013, 43, 322-338, [CrossRef]

18. Stehfest, E.; Bouwman, L. $\mathrm{N}_{2} \mathrm{O}$ and $\mathrm{NO}$ emission from agricultural fields and soils under natural vegetation: Summarizing available measurement data and modeling of global annual emissions. Nutr. Cycl. Agroecosystems 2006, 74, 207-228. [CrossRef]

19. Aguilera, E.; Lassaletta, L.; Sanz-Cobena, A.; Garnier, J.; Vallejo, A. The potential of organic fertilizers and water management to reduce $\mathrm{N}_{2} \mathrm{O}$ emissions in Mediterranean climate cropping systems. A review. Agric. Ecosyst. Environ. 2013, 164, 32-52. [CrossRef]

20. Bouwman, A.F.; Boumans, L.J.M.; Batjes, N.H. Modeling global annual $\mathrm{N}_{2} \mathrm{O}$ and NO emissions from fertilized fields. Glob. Biogeochem. Cycles 2002, 16, 28. [CrossRef]

21. Charles, A.; Rochette, P.; Whalen, J.K.; Angers, D.A.; Chantigny, M.H.; Bertrand, N. Global nitrous oxide emission factors from agricultural soils after addition of organic amendments: A meta-analysis. Agric. Ecosyst. Environ. 2017, 236, 88-98. [CrossRef]

22. Dalal, R.C.; Wang, W.; Robertson, G.P.; Parton, W.J. Nitrous oxide emission from Australian agricultural lands and mitigation options: A review. Soil Res. 2003, 41, 165-195. [CrossRef]

23. Uchida, Y.; Akiyama, H. Mitigation of postharvest nitrous oxide emissions from soybean ecosystems: A review. Soil Sci. Plant Nutr. 2013, 59, 477-487. [CrossRef]

24. Weier, K.L.; Doran, J.W.; Power, J.F.; Walters, D.T. Denitrification and the Dinitrogen/Nitrous Oxide Ratio as Affected by Soil Water, Available Carbon, and Nitrate. Soil Sci. Soc. Am. J. 1993, 57, 66-72. [CrossRef]

25. Parton, W.J.; Mosier, A.R.; Ojima, D.S.; Valentine, D.W.; Schimel, D.S.; Weier, K.; Kulmala, A.E. Generalized model for N2 2 and $\mathrm{N}_{2} \mathrm{O}$ production from nitrification and denitrification. Glob. Biogeochem. Cycles 1996, 10, 401-412. [CrossRef]

26. Cameron, K.C.; Di, H.; Moir, J.L. Nitrogen losses from the soil/plant system: A review. Ann. Appl. Biol. 2013, 162, 145-173. [CrossRef]

27. Oertel, C.; Matschullat, J.; Zurba, K.; Zimmermann, F.; Erasmi, S. Greenhouse gas emissions from soils-A review. Geochemistry 2016, 76, 327-352. [CrossRef]

28. Ghimire, U.; Shrestha, N.K.; Biswas, A.; Wagner-Riddle, C.; Yang, W.; Prasher, S.; Rudra, R.; Daggupati, P. A Review of Ongoing Advancements in Soil and Water Assessment Tool (SWAT) for Nitrous Oxide ( $\mathrm{N}_{2} \mathrm{O}$ ) Modeling. Atmosphere 2020, 11, 450. [CrossRef]

29. Saggar, S.; Jha, N.; Deslippe, J.; Bolan, N.S.; Luo, J.; Giltrap, D.L.; Kim, D.-G.; Zaman, M.; Tillman, R.W. Denitrification and $\mathrm{N}_{2} \mathrm{O}: \mathrm{N}_{2}$ production in temperate grasslands: Processes, measurements, modelling and mitigating negative impacts. Sci. Total. Environ. 2013, 465, 173-195. [CrossRef] [PubMed]

30. Parton, W.J.; Holland, E.A.; Del Grosso, S.J.; Hartman, M.D.; Martin, R.E.; Mosier, A.R.; Ojima, D.S.; Schimel, D.S. Generalized model for NOxand $\mathrm{N}_{2} \mathrm{O}$ emissions from soils. J. Geophys. Res. Space Phys. 2001, 106, 17403-17419. [CrossRef]

31. Li, Y.; Chen, D.; Zhang, Y.; Edis, R.; Ding, H. Comparison of three modeling approaches for simulating denitrification and nitrous oxide emissions from loam-textured arable soils. Glob. Biogeochem. Cycles 2005, 19, 1-15. [CrossRef] 
32. Arnold, J.G.; Srinivasan, R.; Muttiah, R.S.; Williams, J.R. Large area hydrologic modeling and assessment part I: Model development. JAWRA J. Am. Water Resour. Assoc. 1998, 34, 73-89. [CrossRef]

33. Wu, L.; Rees, R.; Tarsitano, D.; Zhang, X.; Jones, S.; Whitmore, A. Simulation of nitrous oxide emissions at field scale using the SPACSYS model. Sci. Total. Environ. 2015, 530-531, 76-86. [CrossRef] [PubMed]

34. Blackmer, A.M.; Bremner, J.M. Inhibitory effect of nitrate on reduction of $\mathrm{N}_{2} \mathrm{O}$ to $\mathrm{N}_{2}$ by soil microorganisms. Soil Biol. Biochem. 1978, 10, 187-191. [CrossRef]

35. Williams, E.J.; Hutchinson, G.L.; Fehsenfeld, F.C. $\mathrm{NO}_{\mathrm{x}}$ and $\mathrm{N}_{2} \mathrm{O}$ Emissions from Soil. Glob. Biogeochem. Cycles 1992, 6, 351-388. [CrossRef]

36. Bremner, J.M. Sources of nitrous oxide in soils. Nutr. Cycl. Agroecosystems 1997, 49, 7-16. [CrossRef]

37. Chen, G.; Kolb, L.; Cavigelli, M.A.; Weil, R.R.; Hooks, C.R. Can conservation tillage reduce $\mathrm{N}_{2} \mathrm{O}$ emissions on cropland transitioning to organic vegetable production? Sci. Total. Environ. 2018, 618, 927-940. [CrossRef] [PubMed]

38. Mehnaz, K.R.; Keitel, C.; Dijkstra, F.A. Effects of carbon and phosphorus addition on microbial respiration, $\mathrm{N}_{2} \mathrm{O}$ emission, and gross nitrogen mineralization in a phosphorus-limited grassland soil. Biol. Fertil. Soils 2018, 54, 481-493. [CrossRef]

39. Butterbach-Bahl, K.; Baggs, E.M.; Dannenmann, M.; Kiese, R.; Zechmeister-Boltenstern, S. Nitrous oxide emissions from soils: How well do we understand the processes and their controls? Philos. Trans. R. Soc. B Biol. Sci. 2013, 368, 20130122. [CrossRef]

40. Steinbach, H.S.; Alvarez, R. Changes in Soil Organic Carbon Contents and Nitrous Oxide Emissions after Introduction of No-Till in Pampean Agroecosystems. J. Environ. Qual. 2006, 35, 3-13. [CrossRef] [PubMed]

41. Chen, N.; Liao, T.-T.; Wang, R.; Zheng, X.-H.; Hu, R.-G.; Butterbach-Bahl, K. Effect of carbon substrate concentration on $\mathrm{N}_{2}$, $\mathrm{N}_{2} \mathrm{O}$, $\mathrm{NO}, \mathrm{CO}_{2}$, and $\mathrm{CH} 4$ emissions from a paddy soil in anaerobic condition. Huan Jing Ke Xue 2014, 35, 3595-3604.

42. Stein, L.Y.; Yung, Y.L. Production, isotopic composition, and atmospheric fate of biologically produced nitrous oxide. Annu. Rev. Earth Planet. Sci. 2003, 31, 329-356. [CrossRef]

43. Benckiser, G.; Eilts, R.; Linn, A.; Lorch, H.J.; Sümer, E.; Weiske, A.; Wenzhöfer, F. $\mathrm{N}_{2} \mathrm{O}$ emissions from different cropping systems and from aerated, nitrifying and denitrifying tanks of a municipal waste water treatment plant. Biol. Fertil. Soils 1996, 23, 257-265. [CrossRef]

44. Miller, M.N.; Zebarth, B.; Dandie, C.E.; Burton, D.L.; Goyer, C.; Trevors, J.T. Crop residue influence on denitrification, $\mathrm{N}_{2} \mathrm{O}$ emissions and denitrifier community abundance in soil. Soil Biol. Biochem. 2008, 40, 2553-2562. [CrossRef]

45. Köster, J.R.; Cárdenas, L.M.; Bol, R.; Lewicka-Szczebak, D.; Senbayram, M.; Well, R.; Giesemann, A.; Dittert, K. Anaerobic digestates lower $\mathrm{N}_{2} \mathrm{O}$ emissions compared to cattle slurry by affecting rate and product stoichiometry of denitrification-An $\mathrm{N}_{2} \mathrm{O}$ isotopomer case study. Soil Biol. Biochem. 2015, 84, 65-74. [CrossRef]

46. Ribas, A.; Mattana, S.; Llurba, R.; Debouk, H.; Sebastià, M.; Domene, X. Biochar application and summer temperatures reduce $\mathrm{N}_{2} \mathrm{O}$ and enhance $\mathrm{CH} 4$ emissions in a Mediterranean agroecosystem: Role of biologically-induced anoxic microsites. Sci. Total. Environ. 2019, 685, 1075-1086. [CrossRef] [PubMed]

47. Feng, Z.; Zhu, L. Impact of biochar on soil $\mathrm{N}_{2} \mathrm{O}$ emissions under different biochar-carbon/fertilizer-nitrogen ratios at a constant moisture condition on a silt loam soil. Sci. Total. Environ. 2017, 584-585, 776-782. [CrossRef]

48. Butterbach-Bahl, K.; Dannenmann, M. Denitrification and associated soil $\mathrm{N}_{2} \mathrm{O}$ emissions due to agricultural activities in a changing climate. Curr. Opin. Environ. Sustain. 2011, 3, 389-395. [CrossRef]

49. Smith, K.A. Changing views of nitrous oxide emissions from agricultural soil: Key controlling processes and assessment at different spatial scales. Eur. J. Soil Sci. 2017, 68, 137-155. [CrossRef]

50. Farquharson, R. Nitrification rates and associated nitrous oxide emissions from agricultural soils-A synopsis. Soil Res. 2016, 54, 469-480. [CrossRef]

51. Bol, R.; Toyoda, S.; Yamulki, S.; Hawkins, J.M.B.; Cardenas, L.M.; Yoshida, N. Dual isotope and isotopomer ratios of $\mathrm{N}_{2} \mathrm{O}$ emitted from a temperate grassland soil after fertiliser application. Rapid Commun. Mass Spectrom. 2003, 17, 2550-2556. [CrossRef] [PubMed]

52. Scholefield, D.; Hawkins, J.M.B.; Jackson, S.M. Use of a flowing helium atmosphere incubation technique to measure the effects of denitrification controls applied to intact cores of a clay soil. Soil Biol. Biochem. 1997, 29, 1337-1344. [CrossRef]

53. Bateman, E.J.; Baggs, E.M. Contributions of nitrification and denitrification to $\mathrm{N}_{2} \mathrm{O}$ emissions from soils at different water-filled pore space. Biol. Fertil. Soils 2005, 41, 379-388. [CrossRef]

54. Ciarlo, E.; Conti, M.; Bartoloni, N.; Rubio, G. The effect of moisture on nitrous oxide emissions from soil and the $\mathrm{N}_{2} \mathrm{O} /\left(\mathrm{N}_{2} \mathrm{O}+\mathrm{N}_{2}\right)$ ratio under laboratory conditions. Biol. Fertil. Soils 2006, 43, 675-681. [CrossRef]

55. Friedl, J.; Scheer, C.; Rowlings, D.W.; McIntosh, H.V.; Strazzabosco, A.; Warner, D.I.; Grace, P.R. Denitrification losses from an intensively managed sub-tropical pasture-Impact of soil moisture on the partitioning of $\mathrm{N}_{2}$ and $\mathrm{N}_{2} \mathrm{O}$ emissions. Soil Biol. Biochem. 2016, 92, 58-66. [CrossRef]

56. Ruser, R.; Flessa, H.; Russow, R.; Schmidt, G.; Buegger, F.; Munch, J. Emission of $\mathrm{N}_{2} \mathrm{O}, \mathrm{N}_{2}$ and $\mathrm{CO}_{2}$ from soil fertilized with nitrate: Effect of compaction, soil moisture and rewetting. Soil Biol. Biochem. 2006, 38, 263-274. [CrossRef]

57. Wu, D.; Cárdenas, L.M.; Calvet, S.; Brüggemann, N.; Loick, N.; Liu, S.; Bol, R. The effect of nitrification inhibitor on $\mathrm{N}_{2} \mathrm{O}, \mathrm{NO}$ and $\mathrm{N}_{2}$ emissions under different soil moisture levels in a permanent grassland soil. Soil Biol. Biochem. 2017, 113, 153-160. [CrossRef]

58. Choudhary, M.A.; Akramkhanov, A.; Saggar, S. Nitrous oxide emissions in soils cropped with maize under long-term tillage and under permanent pasture in New Zealand. Soil Tillage Res. 2001, 62, 61-71. [CrossRef] 
59. Schwenke, G.D.; Haigh, B.M. The interaction of seasonal rainfall and nitrogen fertiliser rate on soil $\mathrm{N}_{2} \mathrm{O}$ emission, total $\mathrm{N}$ loss and crop yield of dryland sorghum and sunflower grown on sub-tropical Vertosols. Soil Res. 2016, 54, 604-618. [CrossRef]

60. Lesschen, J.P.; Velthof, G.L.; De Vries, W.; Kros, J. Differentiation of nitrous oxide emission factors for agricultural soils. Environ. Pollut. 2011, 159, 3215-3222. [CrossRef] [PubMed]

61. Meurer, K.H.; Franko, U.; Stange, C.F.; Dalla Rosa, J.; Madari, B.E.; Jungkunst, H.F. Direct nitrous oxide ( $\left.\mathrm{N}_{2} \mathrm{O}\right)$ fluxes from soils under different land use in Brazil-A critical review. Environ. Res. Lett. 2016, 11, 23001. [CrossRef]

62. Xu, Y.; Xu, Z.; Cai, Z.; Reverchon, F. Review of denitrification in tropical and subtropical soils of terrestrial ecosystems. J. Soils Sediments 2013, 13, 699-710. [CrossRef]

63. Hefting, M.M.; Bobbink, R.; De Caluwe, H. Nitrous Oxide Emission and Denitrification in Chronically Nitrate-Loaded Riparian Buffer Zones. J. Environ. Qual. 2003, 32, 1194-1203. [CrossRef]

64. Hénault, C.; Grossel, A.; Mary, B.; Roussel, M.; Léonard, J. Nitrous Oxide Emission by Agricultural Soils: A Review of Spatial and Temporal Variability for Mitigation. Pedosphere 2012, 22, 426-433. [CrossRef]

65. Lai, T.V.; Farquharson, R.; Denton, M.D. High soil temperatures alter the rates of nitrification, denitrification and associated $\mathrm{N}_{2} \mathrm{O}$ emissions. J. Soils Sediments 2019, 19, 2176-2189. [CrossRef]

66. Prentice, I.C. Terrestrial nitrogen cycle simulation with a dynamic global vegetation model. Glob. Chang. Biol. 2008, 14, 1745-1764. [CrossRef]

67. Lai, T.V.; Denton, M.D. $\mathrm{N}_{2} \mathrm{O}$ and $\mathrm{N}_{2}$ emissions from denitrification respond differently to temperature and nitrogen supply. $J$. Soils Sediments 2018, 18, 1548-1557. [CrossRef]

68. Sun, X.; Han, X.; Ping, F.; Zhang, L.; Zhang, K.; Chen, M.; Wu, W. Effect of rice-straw biochar on nitrous oxide emissions from paddy soils under elevated $\mathrm{CO}_{2}$ and temperature. Sci. Total. Environ. 2018, 628, 1009-1016. [CrossRef] [PubMed]

69. Vargas, V.P.; Soares, J.R.; Oliveira, B.G.; Lourenço, K.S.; Martins, A.A.; Del Grosso, S.J.; Carmo, J.B.D.; Cantarella, H. Sugarcane Straw, Soil Temperature, and Nitrification Inhibitor Impact $\mathrm{N}_{2} \mathrm{O}$ Emissions from N Fertilizer. BioEnergy Res. 2019, 12, 801-812. [CrossRef]

70. Maag, M.; Vinther, F. Nitrous oxide emission by nitrification and denitrification in different soil types and at different soil moisture contents and temperatures. Appl. Soil Ecol. 1996, 4, 5-14. [CrossRef]

71. Lassey, K.; Harvey, M. Nitrous oxide: The serious side of laughing gas. Water Atmos. 2007, 15, 10-11. Available online: https:/ / niwa.co.nz/sites/niwa.co.nz/files/import/attachments/oxide.pdf (accessed on 26 February 2019).

72. Clough, T.J.; Sherlock, R.R.; Kelliher, F.M. Can liming mitigate $\mathrm{N}_{2} \mathrm{O}$ fluxes from a urine-amended soil? Soil Res. 2003, 41, 439-457. [CrossRef]

73. Šimek, M.; Cooper, J.E. The influence of soil $\mathrm{pH}$ on denitrification: Progress towards the understanding of this interaction over the last 50 years. Eur. J. Soil Sci. 2002, 53, 345-354. [CrossRef]

74. Rochester, I.J. Estimating nitrous oxide emissions from flood-irrigated alkaline grey clays. Soil Res. 2003, 41, 197-206. [CrossRef]

75. Šimek, M.; Jíšová, L.; Hopkins, D.W. What is the so-called optimum pH for denitrification in soil? Soil Biol. Biochem. 2002, 34, 1227-1234. [CrossRef]

76. Tsuneda, S.; Mikami, M.; Kimochi, Y.; Hirata, A. Effect of salinity on nitrous oxide emission in the biological nitrogen removal process for industrial wastewater. J. Hazard. Mater. 2005, 119, 93-98. [CrossRef] [PubMed]

77. Wei, Q.; Xu, J.; Liao, L.; Li, Y.; Wang, H.; Rahim, S.F. Water Salinity Should Be Reduced for Irrigation to Minimize Its Risk of Increased Soil $\mathrm{N}_{2} \mathrm{O}$ Emissions. Int. J. Environ. Res. Public Health 2018, 15, 2114. [CrossRef] [PubMed]

78. Bell, M.J.; Cloy, J.M.; Topp, C.F.E.; Ball, B.C.; Bagnall, A.; Rees, R.M.; Chadwick, D.R. Quantifying $\mathrm{N}_{2} \mathrm{O}$ emissions from intensive grassland production: The role of synthetic fertilizer type, application rate, timing and nitrification inhibitors. J. Agric. Sci. 2016, 154, 812-827. [CrossRef]

79. Snyder, C.; Bruulsema, T.; Jensen, T.; Fixen, P. Review of greenhouse gas emissions from crop production systems and fertilizer management effects. Agric. Ecosyst. Environ. 2009, 133, 247-266. [CrossRef]

80. Zimmermann, J.; Carolan, R.; Forrestal, P.; Harty, M.; Lanigan, G.; Richards, K.; Roche, L.; Whitfield, M.; Jones, M. Assessing the performance of three frequently used biogeochemical models when simulating $\mathrm{N}_{2} \mathrm{O}$ emissions from a range of soil types and fertiliser treatments. Geochemistry 2018, 331, 53-69. [CrossRef]

81. Leip, A.; Busto, M.; Winiwarter, W. Developing spatially stratified $\mathrm{N}_{2} \mathrm{O}$ emission factors for Europe. Environ. Pollut. 2011, 159, 3223-3232. [CrossRef] [PubMed]

82. Dechow, R.; Freibauer, A. Assessment of German nitrous oxide emissions using empirical modelling approaches. Nutr. Cycl. Agroecosystems 2011, 91, 235-254. [CrossRef]

83. Hoben, J.P.; Gehl, R.J.; Millar, N.; Grace, P.R.; Robertson, G.P. Nonlinear nitrous oxide $\left(\mathrm{N}_{2} \mathrm{O}\right)$ response to nitrogen fertilizer in on-farm corn crops of the US Midwest. Glob. Chang. Biol. 2010, 17, 1140-1152. [CrossRef]

84. Cheng, J.; Lee, X.; Zhou, Z.; Wang, B.; Xing, Y.; Cheng, H. Nitrous oxide emissions from different land use patterns in a typical karst region, Southwest China. Chin. J. Geochem. 2013, 32, 137-145. [CrossRef]

85. de Morais, R.F.; Boddey, R.M.; Urquiaga, S.; Jantalia, C.P.; Alves, B.J. Ammonia volatilization and nitrous oxide emissions during soil preparation and $\mathrm{N}$ fertilization of elephant grass (Pennisetum purpureum Schum.). Soil Biol. Biochem. 2013, 64, 80-88. [CrossRef]

86. Pal, P.; Clough, T.J.; Kelliher, F.M.; Sherlock, R.R. Nitrous Oxide Emissions from In Situ Deposition of 15 N-Labeled Ryegrass Litter in a Pasture Soil. J. Environ. Qual. 2013, 42, 323-331. [CrossRef] 
87. Gao, B.; Ju, X.; Su, F.; Meng, Q.; Oenema, O.; Christie, P.; Chen, X.; Zhang, F. Nitrous oxide and methane emissions from optimized and alternative cereal cropping systems on the North China Plain: A two-year field study. Sci. Total. Environ. 2014, 472, 112-124. [CrossRef] [PubMed]

88. Lebender, U.; Senbayram, M.; Lammel, J.; Kuhlmann, H. Impact of mineral $\mathrm{N}$ fertilizer application rates on $\mathrm{N}_{2} \mathrm{O}$ emissions from arable soils under winter wheat. Nutr. Cycl. Agroecosyst. 2014, 100, 111-120. [CrossRef]

89. Shi, Y.-F.; Wu, W.-L.; Meng, F.-Q.; Zheng, L.; Wang, D.-P.; Ye, H.; Ding, G.-W. Nitrous Oxide and Methane Fluxes during the Maize Season Under Optimized Management in Intensive Farming Systems of the North China Plain. Pedosphere 2014, $24,487-497$. [CrossRef]

90. Sordi, A.; Dieckow, J.; Bayer, C.; Alburquerque, M.A.; Piva, J.T.; Zanatta, J.A.; Tomazi, M.; da Rosa, C.M.; de Moraes, A. Nitrous oxide emission factors for urine and dung patches in a subtropical Brazilian pastureland. Agric. Ecosyst. Environ. 2014, 190, 94-103. [CrossRef]

91. Zhang, Y.; Mu, Y.; Zhou, Y.; Liu, J.; Zhang, C. Nitrous oxide emissions from maize-wheat field during 4 successive years in the North China Plain. Biogeosciences 2014, 11, 1717-1726. [CrossRef]

92. Aita, C.; Schirmann, J.; Pujol, S.B.; Giacomini, S.J.; Rochette, P.; Angers, D.A.; Chantigny, M.H.; Gonzatto, R.; Giacomini, D.A.; Doneda, A.A. Reducing nitrous oxide emissions from a maize-wheat sequence by decreasing soil nitrate concentration: Effects of split application of pig slurry and dicyandiamide. Eur. J. Soil Sci. 2015, 66, 359-368. [CrossRef]

93. Hinton, N.; Cloy, J.; Bell, M.; Chadwick, D.; Topp, C.; Rees, R. Managing fertiliser nitrogen to reduce nitrous oxide emissions and emission intensities from a cultivated Cambisol in Scotland. Geoderma Reg. 2015, 4, 55-65. [CrossRef]

94. Huérfano, X.; Fuertes-Mendizábal, T.; Duñabeitia, M.K.; González-Murua, C.; Estavillo, J.M.; Menéndez, S. Splitting the application of 3,4-dimethylpyrazole phosphate (DMPP): Influence on greenhouse gases emissions and wheat yield and quality under humid Mediterranean conditions. Eur. J. Agron. 2015, 64, 47-57. [CrossRef]

95. Martins, M.R.; Jantalia, C.P.; Polidoro, J.C.; Batista, J.N.; Alves, B.J.; Boddey, R.M.; Urquiaga, S. Nitrous oxide and ammonia emissions from $\mathrm{N}$ fertilization of maize crop under no-till in a Cerrado soil. Soil Tillage Res. 2015, 151, 75-81. [CrossRef]

96. Shepherd, A.; Yan, X.; Nayak, D.; Newbold, J.; Moran, D.; Dhanoa, M.S.; Goulding, K.; Smith, P.; Cárdenas, L.M. Disaggregated $\mathrm{N}_{2} \mathrm{O}$ emission factors in China based on cropping parameters create a robust approach to the IPCC Tier 2 methodology. Atmos. Environ. 2015, 122, 272-281. [CrossRef]

97. van der Weerden, T.; Cox, N.; Luo, J.; Di, H.; Podolyan, A.; Phillips, R.; Saggar, S.; de Klein, C.; Ettema, P.; Rys, G. Refining the New Zealand nitrous oxide emission factor for urea fertiliser and farm dairy effluent. Agric. Ecosyst. Environ. 2016, 222, 133-137. [CrossRef]

98. Harty, M.; Forrestal, P.; Watson, C.; McGeough, K.; Carolan, R.; Elliot, C.; Krol, D.; Laughlin, R.; Richards, K.; Lanigan, G. Reducing nitrous oxide emissions by changing $\mathrm{N}$ fertiliser use from calcium ammonium nitrate (CAN) to urea based formulations. Sci. Total. Environ. 2016, 563-564, 576-586. [CrossRef] [PubMed]

99. Krol, D.; Carolan, R.; Minet, E.; McGeough, K.; Watson, C.; Forrestal, P.; Lanigan, G.; Richards, K. Improving and disaggregating $\mathrm{N}_{2} \mathrm{O}$ emission factors for ruminant excreta on temperate pasture soils. Sci. Total. Environ. 2016, 568, 327-338. [CrossRef] [PubMed]

100. Macdonald, B.C.T.; Denmead, O.T.; White, I.; Naylor, T.; Salter, B.; Wilson, S.R.; Griffith, D.W. Emissions of nitrogen gases from sugarcane soils. In Proceedings of the 2009 Conference of the Australian Society of Sugar Cane Technologists held at Ballina, Ballina, NSW, Australia, 5-8 May 2009; Australian Society of Sugar Cane Technologists. pp. 85-92. Available online: http:/ / hdl.handle.net/11079/14180 (accessed on 4 March 2019).

101. Roche, L.; Forrestal, P.; Lanigan, G.; Richards, K.; Shaw, L.; Wall, D. Impact of fertiliser nitrogen formulation, and N stabilisers on nitrous oxide emissions in spring barley. Agric. Ecosyst. Environ. 2016, 233, 229-237. [CrossRef]

102. Faubert, P.; Lemay-Bélisle, C.; Bertrand, N.; Bouchard, S.; Chantigny, M.H.; Durocher, S.; Paré, M.C.; Rochette, P.; Tremblay, P.; Ziadi, N.; et al. Greenhouse gas emissions following land application of pulp and paper mill sludge on a clay loam soil. Agric. Ecosyst. Environ. 2017, 250, 102-112. [CrossRef]

103. Forte, A.; Fagnano, M.; Fierro, A. Potential role of compost and green manure amendment to mitigate soil GHGs emissions in Mediterranean drip irrigated maize production systems. J. Environ. Manag. 2017, 192, 68-78. [CrossRef]

104. Gillette, K.; Ma, L.; Malone, R.W.; Fang, Q.; Halvorson, A.D.; Hatfield, J.L.; Ahuja, L. Simulating N 2 O emissions under different tillage systems of irrigated corn using RZ-SHAW model. Soil Tillage Res. 2017, 165, 268-278. [CrossRef]

105. Htun, Y.M.; Tong, Y.; Gao, P.; Xiaotang, J. Coupled effects of straw and nitrogen management on N $2 \mathrm{O}$ and CH 4 emissions of rainfed agriculture in Northwest China. Atmos. Environ. 2017, 157, 156-166. [CrossRef]

106. Laville, P.; Bosco, S.; Volpi, I.; Virgili, G.; Neri, S.; Continanza, D.; Bonari, E. Temporal integration of soil $\mathrm{N}_{2} \mathrm{O}$ fluxes: Validation of IPNOA station automatic chamber prototype. Environ. Monit. Assess. 2017, 189, 485. [CrossRef] [PubMed]

107. Krauss, M.; Ruser, R.; Müller, T.; Hansen, S.; Mäder, P.; Gattinger, A. Impact of reduced tillage on greenhouse gas emissions and soil carbon stocks in an organic grass-clover ley-winter wheat cropping sequence. Agric. Ecosyst. Environ. 2017, 239, 324-333. [CrossRef] [PubMed]

108. Pugesgaard, S.; Petersen, S.O.; Chirinda, N.; Olesen, J.E. Crop residues as driver for $\mathrm{N}_{2} \mathrm{O}$ emissions from a sandy loam soil. Agric. For. Meteorol. 2017, 233, 45-54. [CrossRef]

109. Xie, B.; Gu, J.; Yu, J.; Han, G.; Zheng, X.; Xu, Y.; Lin, H. Effects of N Fertilizer Application on Soil $\mathrm{N}_{2} \mathrm{O}$ Emissions and CH4 Uptake: A Two-Year Study in an Apple Orchard in Eastern China. Atmosphere 2017, 8, 181. [CrossRef] 
110. Zhou, M.; Zhu, B.; Wang, X.; Wang, Y. Long-term field measurements of annual methane and nitrous oxide emissions from a Chinese subtropical wheat-rice rotation system. Soil Biol. Biochem. 2017, 115, 21-34. [CrossRef]

111. Badagliacca, G.; Benítez, E.; Amato, G.; Badalucco, L.; Giambalvo, D.; Laudicina, V.A.; Ruisi, P. Long-term effects of contrasting tillage on soil organic carbon, nitrous oxide and ammonia emissions in a Mediterranean Vertisol under different crop sequences. Sci. Total. Environ. 2018, 619-620, 18-27. [CrossRef] [PubMed]

112. Dong, D.; Kou, Y.; Yang, W.; Chen, G.; Xu, H. Effects of urease and nitrification inhibitors on nitrous oxide emissions and nitrifying/denitrifying microbial communities in a rainfed maize soil: A 6-year field observation. Soil Tillage Res. 2018, 180, 82-90. [CrossRef]

113. Plaza-Bonilla, D.; Álvaro-Fuentes, J.; Bareche, J.; Pareja-Sánchez, E.; Justes, É.; Cantero-Martínez, C. No-tillage reduces long-term yield-scaled soil nitrous oxide emissions in rainfed Mediterranean agroecosystems: A field and modelling approach. Agric. Ecosyst. Environ. 2018, 262, 36-47. [CrossRef]

114. Reinsch, T.; Loges, R.; Kluß, C.; Taube, F. Renovation and conversion of permanent grass-clover swards to pasture or crops: Effects on annual N 2 O emissions in the year after ploughing. Soil Tillage Res. 2018, 175, 119-129. [CrossRef]

115. Simon, P.L.; Dieckow, J.; de Klein, C.A.; Zanatta, J.A.; van der Weerden, T.J.; Ramalho, B.; Bayer, C. Nitrous oxide emission factors from cattle urine and dung, and dicyandiamide (DCD) as a mitigation strategy in subtropical pastures. Agric. Ecosyst. Environ. 2018, 267, 74-82. [CrossRef]

116. Campanha, M.M.; de Oliveira, A.D.; Marriel, I.E.; Neto, M.M.G.; Malaquias, J.V.; Landau, E.C.; Filho, M.R.D.A.; Ribeiro, F.P.; de Carvalho, A.M. Effect of soil tillage and $\mathrm{N}$ fertilization on $\mathrm{N}_{2} \mathrm{O}$ mitigation in maize in the Brazilian Cerrado. Sci. Total. Environ. 2019, 692, 1165-1174. [CrossRef] [PubMed]

117. Kasper, M.; Foldal, C.; Kitzler, B.; Haas, E.; Strauss, P.; Eder, A.; Zechmeister-Boltenstern, S.; Amon, B. $\mathrm{N}_{2} \mathrm{O}$ emissions and NO $3-$ leaching from two contrasting regions in Austria and influence of soil, crops and climate: A modelling approach. Nutr. Cycl. Agroecosystems 2019, 113, 95-111. [CrossRef]

118. Mumford, M.; Rowlings, D.; Scheer, C.; De Rosa, D.; Grace, P. Effect of irrigation scheduling on nitrous oxide emissions in intensively managed pastures. Agric. Ecosyst. Environ. 2019, 272, 126-134. [CrossRef]

119. Myrgiotis, V.; Williams, M.; Rees, R.M.; Topp, C.F. Estimating the soil $\mathrm{N}_{2} \mathrm{O}$ emission intensity of croplands in northwest Europe. Biogeosciences 2019, 16, 1641-1655. [CrossRef]

120. Shen, J.; Treu, R.; Wang, J.; Hao, X.; Thomas, B.W. Modeling growing season and annual cumulative nitrous oxide emissions and emission factors from organically fertilized soils planted with barley in Lethbridge, Alberta, Canada. Agric. Syst. 2019, 176, 102654. [CrossRef]

121. Zhang, X.; Meng, F.; Li, H.; Wang, L.; Wu, S.; Xiao, G.; Wu, W. Optimized fertigation maintains high yield and mitigates $\mathrm{N}_{2} \mathrm{O}$ and NO emissions in an intensified wheat-maize cropping system. Agric. Water Manag. 2019, 211, 26-36. [CrossRef]

122. Baral, K.R.; Lærke, P.E.; Petersen, S.O. Nitrous oxide emissions after renovation of festulolium, and mitigation potential of 3,4-dimethyl pyrazole phosphate (DMPP). Geoderma 2020, 376, 114551. [CrossRef]

123. Cowan, N.; Levy, P.; Maire, J.; Coyle, M.; Leeson, S.; Famulari, D.; Carozzi, M.; Nemitz, E.; Skiba, U. An evaluation of four years of nitrous oxide fluxes after application of ammonium nitrate and urea fertilisers measured using the eddy covariance method. Agric. For. Meteorol. 2020, 280, 107812. [CrossRef]

124. Krol, D.; Forrestal, P.; Wall, D.; Lanigan, G.; Sanz-Gomez, J.; Richards, K. Nitrogen fertilisers with urease inhibitors reduce nitrous oxide and ammonia losses, while retaining yield in temperate grassland. Sci. Total. Environ. 2020, 725, 138329. [CrossRef] [PubMed]

125. Kudeyarov, V.N. Nitrous Oxide Emission from Fertilized Soils: An Analytical Review. Eurasian Soil Sci. 2020, 53, $1396-1407$. [CrossRef]

126. Wang, R.; Pan, Z.; Zheng, X.; Ju, X.; Yao, Z.; Butterbach-Bahl, K.; Zhang, C.; Wei, H.; Huang, B. Using field-measured soil N $2 \mathrm{O}$ fluxes and laboratory scale parameterization of $\mathrm{N}_{2} \mathrm{O} /\left(\mathrm{N}_{2} \mathrm{O}+\mathrm{N}_{2}\right)$ ratios to quantify field-scale soil $\mathrm{N}_{2}$ emissions. Soil Biol. Biochem. 2020, 148, 107904. [CrossRef]

127. Pareja-Sánchez, E.; Cantero-Martínez, C.; Álvaro-Fuentes, J.; Plaza-Bonilla, D. Impact of tillage and N fertilization rate on soil $\mathrm{N}_{2} \mathrm{O}$ emissions in irrigated maize in a Mediterranean agroecosystem. Agric. Ecosyst. Environ. 2020, 287, 106687. [CrossRef]

128. Yang, Y.; Tong, Y.; Gao, P.; Htun, Y.M.; Feng, T. Evaluation of $\mathrm{N}_{2} \mathrm{O}$ emission from rainfed wheat field in northwest agricultural land in China. Environ. Sci. Pollut. Res. 2020, 27, 43466-43479. [CrossRef] [PubMed]

129. Grave, R.A.; Nicoloso, R.D.S.; Cassol, P.C.; da Silva, M.L.B.; Mezzari, M.P.; Aita, C.; Wuaden, C.R. Determining the effects of tillage and nitrogen sources on soil $\mathrm{N}_{2} \mathrm{O}$ emission. Soil Tillage Res. 2018, 175, 1-12. [CrossRef]

130. Chen, S.; Hao, T.; Goulding, K.; Misselbrook, T.; Liu, X. Impact of 13-years of nitrogen addition on nitrous oxide and methane fluxes and ecosystem respiration in a temperate grassland. Environ. Pollut. 2019, 252, 675-681. [CrossRef] [PubMed]

131. Bordoloi, N.; Baruah, K.K.; Bhattacharyya, P. Emission estimation of nitrous oxide $\left(\mathrm{N}_{2} \mathrm{O}\right)$ from a wheat cropping system under varying tillage practices and different levels of nitrogen fertiliser. Soil Res. 2016, 54, 767-776. [CrossRef]

132. Schwenke, G.D.; Haigh, B.M. Can split or delayed application of $\mathrm{N}$ fertiliser to grain sorghum reduce soil $\mathrm{N}_{2} \mathrm{O}$ emissions from sub-tropical Vertosols and maintain grain yields? Soil Res. 2019, 57, 859-874. [CrossRef]

133. Yang, X.M.; Drury, C.F.; Reeb, M.R. No-Tillage had Warmer Over-Winter Soil Temperatures than Conventional Tillage in a Brookston Clay Loam Soils in Southwestern Ontario. Soil Sci. Soc. Am. J. 2018, 82, 307-314. [CrossRef] 
134. Žurovec, O.; Sitaula, B.K.; Čustović, H.; Žurovec, J.; Dörsch, P. Effects of tillage practice on soil structure, $\mathrm{N}_{2} \mathrm{O}$ emissions and economics in cereal production under current socio-economic conditions in central Bosnia and Herzegovina. PLoS ONE 2017, 12, e0187681. [CrossRef]

135. Wang, J.; Chadwick, D.R.; Cheng, Y.; Yan, X. Global analysis of agricultural soil denitrification in response to fertilizer nitrogen. Sci. Total. Environ. 2018, 616-617, 908-917. [CrossRef]

136. Duan, Y.-F.; Hallin, S.; Jones, C.M.; Priemé, A.; Labouriau, R.; Petersen, S.O. Catch Crop Residues Stimulate $\mathrm{N}_{2} \mathrm{O}$ Emissions during Spring, Without Affecting the Genetic Potential for Nitrite and $\mathrm{N}_{2} \mathrm{O}$ Reduction. Front. Microbiol. 2018, 9, 2629. [CrossRef] [PubMed]

137. Yuan, M.; Greer, K.D.; Nafziger, E.D.; Villamil, M.B.; Pittelkow, C.M. Soil $\mathrm{N}_{2} \mathrm{O}$ emissions as affected by long-term residue removal and no-till practices in continuous corn. GCB Bioenergy 2018, 10, 972-985. [CrossRef]

138. Badagliacca, G.; Ruisi, P.; Rees, R.M.; Saia, S. An assessment of factors controlling $\mathrm{N}_{2} \mathrm{O}$ and $\mathrm{CO}_{2}$ emissions from crop residues using different measurement approaches. Biol. Fertil. Soils 2017, 53, 547-561. [CrossRef]

139. Liu, F.; Zhang, Y.; Liang, H.; Gao, D. Long-term harvesting of reeds affects greenhouse gas emissions and microbial functional genes in alkaline wetlands. Water Res. 2019, 164, 114936. [CrossRef] [PubMed]

140. da Silva Cardoso, A.; de Figueiredo Brito, L.; Janusckiewicz, E.R.; da Silva Morgado, E.; Barbero, R.P.; Koscheck, J.F.W.; Reis, R.A.; Ruggieri, A.C. Impact of Grazing Intensity and Seasons on Greenhouse Gas Emissions in Tropical Grassland. Ecosystems 2017, 20, 845-859. [CrossRef]

141. Deng, J.; Li, C.; Burger, M.; Horwath, W.R.; Smart, D.; Six, J.; Guo, L.; Salas, W.; Frolking, S. Assessing Short-Term Impacts of Management Practices on $\mathrm{N}_{2} \mathrm{O}$ Emissions from Diverse Mediterranean Agricultural Ecosystems Using a Biogeochemical Model. J. Geophys. Res. Biogeosci. 2018, 123, 1557-1571. [CrossRef]

142. Smith, K.A.; McTaggart, I.P.; Tsuruta, H. Emissions of $\mathrm{N}_{2} \mathrm{O}$ and $\mathrm{NO}$ associated with nitrogen fertilization in intensive agriculture, and the potential for mitigation. Soil Use Manag. 1997, 13, 296-304. [CrossRef]

143. Trost, B.; Prochnow, A.; Drastig, K.; Meyer-Aurich, A.; Ellmer, F.; Baumecker, M. Irrigation, soil organic carbon and $\mathrm{N}_{2} \mathrm{O}$ emissions. A review. Agron. Sustain. Dev. 2013, 33, 733-749. [CrossRef]

144. Sánchez-Martín, L.; Arce, A.; Benito, A.; Garcia-Torres, L.; Vallejo, A. Influence of drip and furrow irrigation systems on nitrogen oxide emissions from a horticultural crop. Soil Biol. Biochem. 2008, 40, 1698-1706. [CrossRef]

145. Tang, J.; Wang, J.; Li, Z.; Wang, S.; Qu, Y. Effects of Irrigation Regime and Nitrogen Fertilizer Management on $\mathrm{CH}_{4}, \mathrm{~N}_{2} \mathrm{O}$ and $\mathrm{CO}_{2}$ Emissions from Saline-Alkaline Paddy Fields in Northeast China. Sustainability 2018, 10, 475. [CrossRef]

146. Ye, X.; Liu, H.; Zhang, X.; Ma, J.; Han, B.; Li, W.; Zou, H.; Zhang, Y.; Lin, X. Impacts of irrigation methods on greenhouse gas emissions/absorptions from vegetable soils. J. Soils Sediments 2019, 20, 723-733. [CrossRef]

147. Shang, Z.; Abdalla, M.; Kuhnert, M.; Albanito, F.; Zhou, F.; Xia, L.; Smith, P. Measurement of $\mathrm{N}_{2} \mathrm{O}$ emissions over the whole year is necessary for estimating reliable emission factors. Environ. Pollut. 2020, 259, 113864. [CrossRef]

148. Groffman, P.M.; Altabet, M.A.; Böhlke, J.K.; Butterbach-Bahl, K.; David, M.B.; Firestone, M.K.; Giblin, A.E.; Kana, T.M.; Nielsen, L.P.; Voytek, M.A. Methods for Measuring Denitrification: Diverse Approaches to a Difficult Problem. Ecol. Appl. 2006, 16, 2091-2122. [CrossRef]

149. Beauchamp, E.G. Nitrous oxide emission from agricultural soils. Can. J. Soil Sci. 1997, 77, 113-123. [CrossRef]

150. Skiba, U.; Hargreaves, K.; Fowler, D.; Smith, K. Fluxes of nitric and nitrous oxides from agricultural soils in a cool temperate climate. Atmos. Environ. Part A. Gen. Top. 1992, 26, 2477-2488. [CrossRef]

151. Schäfer, K.G.; Böttcher, J.; Weymann, D.; Von Der Heide, C.; Duijnisveld, W.H.M. Evaluation of a Closed Tunnel for Field-Scale Measurements of Nitrous Oxide Fluxes from an Unfertilized Grassland Soil. J. Environ. Qual. 2012, 41, 1383-1392. [CrossRef] [PubMed]

152. Venterea, R.T. Simplified Method for Quantifying Theoretical Underestimation of Chamber-Based Trace Gas Fluxes. J. Environ. Qual. 2010, 39, 126-135. [CrossRef] [PubMed]

153. Hensen, A.; Skiba, U.; Famulari, D. Low cost and state of the art methods to measure nitrous oxide emissions. Environ. Res. Lett. 2013, 8, 025022. [CrossRef]

154. Adu, J.; Kumarasamy, M.V. Assessing Non-Point Source Pollution Models: A Review. Pol. J. Environ. Stud. 2018, 27, 1913-1922. [CrossRef]

155. Frolking, S.; Mosier, A.; Ojima, D.; Li, C.; Parton, W.; Potter, C.; Priesack, E.; Stenger, R.; Haberbosch, C.; Dörsch, P.; et al. Comparison of $\mathrm{N}_{2} \mathrm{O}$ emissions from soils at three temperate agricultural sites: Simulations of year-round measurements by four models. Nutr. Cycl. Agroecosyst. 1998, 52, 77-105. [CrossRef]

156. Heinen, M. Simplified denitrification models: Overview and properties. Geoderma 2006, 133, 444-463. [CrossRef]

157. Li, X.; Yeluripati, J.; Jones, E.O.; Uchida, Y.; Hatano, R. Hierarchical Bayesian calibration of nitrous oxide ( $\left.\mathrm{N}_{2} \mathrm{O}\right)$ and nitrogen monoxide (NO) flux module of an agro-ecosystem model: ECOSSE. Ecol. Model. 2015, 316, 14-27. [CrossRef]

158. Snow, V.; Rotz, C.; Moore, A.; Martin-Clouaire, R.; Johnson, I.; Hutchings, N.; Eckard, R. The challenges-and some solutions-to process-based modelling of grazed agricultural systems. Environ. Model. Softw. 2014, 62, 420-436. [CrossRef]

159. Williams, J.R.; Izaurralde, R.C.; Steglich, E.M. Agricultural policy/environmental extender model. Theor. Doc. 2008, 604, 20082017. Available online: https:/ / agrilifecdn.tamu.edu/epicapex/files/2017/03/THE-APEX0806-theoretical-documentation-Oct2015.pdf (accessed on 21 December 2018). 
160. Lehuger, S.; Gabrielle, B.; Van Oijen, M.; Makowski, D.; Germon, J.-C.; Morvan, T.; Hénault, C. Bayesian calibration of the nitrous oxide emission module of an agro-ecosystem model. Agric. Ecosyst. Environ. 2009, 133, 208-222. [CrossRef]

161. Youssef, M.A.; Skaggs, R.W.; Chescheir, G.M.; Gilliam, J.W. The nitrogen simulation model, DRAINMOD-N II. Trans. ASAE 2005, 48, 611-626. [CrossRef]

162. Gassman, P.W.; Williams, J.R.; Benson, V.W.; Izaurralde, R.C.; Hauck, L.M.; Jones, C.A.; Atwood, J.D.; Kiniry, J.R.; Flowers, J.D. Historical development and applications of the EPIC and APEX models. In Proceedings of the 2005 ASAE Annual Meeting (p. 1). American Society of Agricultural and Biological Engineers, Ottawa, ON, Canada, 1-4 August 2004; p. 1. [CrossRef]

163. Chatskikh, D.; Olesen, J.E.; Berntsen, J.; Regina, K.; Yamulki, S. Simulation of Effects of Soils, Climate and Management on $\mathrm{N}_{2} \mathrm{O}$ Emission from Grasslands. Biogeochemistry 2005, 76, 395-419. [CrossRef]

164. Zhang, K.; Peng, C.; Wang, M.; Zhou, X.; Li, M.; Wang, K.; Ding, J.; Zhu, Q. Process-based TRIPLEX-GHG model for simulating $\mathrm{N}_{2} \mathrm{O}$ emissions from global forests and grasslands: Model development and evaluation. J. Adv. Model. Earth Syst. 2017, 9, 2079-2102. [CrossRef]

165. Adams, H.D.; Williams, A.P.; Xu, C.; Rauscher, S.A.; Jiang, X.; McDowell, N.G. Empirical and process-based approaches to climate-induced forest mortality models. Front. Plant Sci. 2013, 4, 438. [CrossRef]

166. Izaurralde, R.C.; McGill, W.B.; Williams, J.R.; Jones, C.D.; Link, R.P.; Manowitz, D.H.; Schwab, D.E.; Zhang, X.; Robertson, G.P.; Millar, N. Simulating microbial denitrification with EPIC: Model description and evaluation. Ecol. Model. 2017, 359, 349-362. [CrossRef]

167. Foltz, M.E.; Zilles, J.L.; Koloutsou-Vakakis, S. Prediction of $\mathrm{N}_{2} \mathrm{O}$ emissions under different field management practices and climate conditions. Sci. Total. Environ. 2019, 646, 872-879. [CrossRef]

168. Bouraoui, F.; Grizzetti, B. Modelling mitigation options to reduce diffuse nitrogen water pollution from agriculture. Sci. Total. Environ. 2014, 468-469, 1267-1277. [CrossRef] [PubMed]

169. Shrestha, N.K.; Thomas, B.W.; Du, X.; Hao, X.; Wang, J. Modeling nitrous oxide emissions from rough fescue grassland soils subjected to long-term grazing of different intensities using the Soil and Water Assessment Tool (SWAT). Environ. Sci. Pollut. Res. 2018, 25, 27362-27377. [CrossRef] [PubMed]

170. Shrestha, N.K.; Wang, J. Current and future hot-spots and hot-moments of nitrous oxide emission in a cold climate river basin. Environ. Pollut. 2018, 239, 648-660. [CrossRef] [PubMed]

171. Tian, H.; Yang, J.; Lu, C.; Xu, R.; Canadell, J.G.; Jackson, R.B.; Arneth, A.; Chang, J.; Chen, G.; Ciais, P.; et al. The global N $2 \mathrm{O}$ Model Intercomparison Project. Bull. Am. Meteorol. Soc. 2018, 99, 1231-1251. [CrossRef]

172. Li, C. User's Guide for the DNDC Model (Version 9.5) 2012. University of New Hampshire. Available online: http:/ /www.dndc sr.unh.edu/model/GuideDNDC95.pdf (accessed on 25 January 2020).

173. Neitsch, S.L.; Arnold, J.G.; Kiniry, J.R.; Williams, J.R. Soil and water assessment tool theoretical documentation version 2009. Texas Wat. Resour. Inst. 2011. Available online: https://swat.tamu.edu/media/99192/swat2009-theory.pdf (accessed on 9 March 2018).

174. Yang, Q.; Zhang, X.; Abraha, M.; Del Grosso, S.; Robertson, G.P.; Chen, J. Enhancing the soil and water assessment tool model for simulating $\mathrm{N}_{2} \mathrm{O}$ emissions of three agricultural systems. Ecosyst. Health Sustain. 2017, 3, e01259. [CrossRef]

175. Wagena, M.B.; Bock, E.M.; Sommerlot, A.R.; Fuka, D.R.; Easton, Z.M. Development of a nitrous oxide routine for the SWAT model to assess greenhouse gas emissions from agroecosystems. Environ. Model. Softw. 2017, 89, 131-143. [CrossRef]

176. David, M.B.; Del Grosso, S.J.; Hu, X.; Marshall, E.P.; McIsaac, G.F.; Parton, W.J.; Tonitto, C.; Youssef, M.A. Modeling denitrification in a tile-drained, corn and soybean agroecosystem of Illinois, USA. Biogeochemistry 2009, 93, 7-30. [CrossRef]

177. Del Grosso, S.J.; Parton, W.J.; Adler, P.R.; Davis, S.C.; Keough, C.; Marx, E. DayCent model simulations for estimating soil carbon dynamics and greenhouse gas fluxes from agricultural production systems. In Managing Agricultural Greenhouse Gases: Coordinated Agricultural Research through GRACEnet to Address our Changing Climate; Academic Press: San Diego, CA, USA, 2012 ; pp. 241-250.

178. Bosatta, E. A qualitative analysis of the stability of the root-microorganism soil system I. carbon-nitrogen status and nitrogen mineralization. Ecol. Model. 1981, 13, 223-236. [CrossRef]

179. Cui, F.; Zheng, X.; Liu, C.; Wang, K.; Zhou, Z.; Deng, J. Assessing biogeochemical effects and best management practice for a wheat-maize cropping system using the DNDC model. Biogeosciences 2014, 11, 91-107. [CrossRef]

180. Gaillard, R.K.; Jones, C.D.; Ingraham, P.; Collier, S.; Izaurralde, R.C.; Jokela, W.; Osterholz, W.; Salas, W.; Vadas, P.; Ruark, M.D. Underestimation of $\mathrm{N}_{2} \mathrm{O}$ emissions in a comparison of the DayCent, DNDC, and EPIC models. Ecol. Appl. 2018, 28, 694-708. [CrossRef]

181. Fitton, N.; Datta, A.; Smith, K.; Williams, J.R.; Hastings, A.; Kuhnert, M.; Topp, C.F.E.; Smith, P. Assessing the sensitivity of modelled estimates of $\mathrm{N}_{2} \mathrm{O}$ emissions and yield to input uncertainty at a UK cropland experimental site using the DailyDayCent model. Nutr. Cycl. Agroecosyst. 2014, 99, 119-133. [CrossRef]

182. Necpálová, M.; Anex, R.P.; Fienen, M.N.; Del Grosso, S.J.; Castellano, M.J.; Sawyer, J.E.; Iqbal, J.; Pantoja, J.L.; Barker, D.W. Understanding the DayCent model: Calibration, sensitivity, and identifiability through inverse modeling. Environ. Model. Softw. 2015, 66, 110-130. [CrossRef]

183. Myrgiotis, V.; Rees, R.M.; Topp, C.F.; Williams, M. A systematic approach to identifying key parameters and processes in agroecosystem models. Ecol. Model. 2018, 368, 344-356. [CrossRef] 
184. Wang, G.; Chen, S. A review on parameterization and uncertainty in modeling greenhouse gas emissions from soil. Geoderma 2012, 170, 206-216. [CrossRef]

185. Myrgiotis, V.; Williams, M.; Rees, R.M.; Smith, K.E.; Thorman, R.E.; Topp, C.F. Model evaluation in relation to soil $\mathrm{N}_{2} \mathrm{O}$ emissions: An algorithmic method which accounts for variability in measurements and possible time lags. Environ. Model. Softw. 2016, 84, 251-262. [CrossRef] 